\section{Mitigation of the Impact of Vascular Wilt and Soil Hypoxia on Cape Gooseberry Plants by Foliar Application of Synthetic Elicitors}

\author{
Cristhian Camilo Chávez-Arias, Sandra Gómez-Caro, \\ and Hermann Restrepo-Díaz \\ Departamento de Agronomía, Facultad de Ciencias Agrarias, Universidad \\ Nacional de Colombia, Bogotá, Colombia
}

Additional index words. Andean fruit species, F. oxysporum, stress interactions, synthetic elicitor, waterlogging

\begin{abstract}
Physalis peruviana L. crops are exposed to different stress conditions that limit their productivity. Within these conditions, abiotic stress caused by water and biotic stress by Fusarium oxysporum f. sp. physali (Foph) are frequent at commercial levels. The foliar application of synthetic elicitors can be a tool to mitigate the negative impacts of these stresses. The objective of this study was to evaluate the interaction between Foph inoculation and three foliar applications of brassinosteroids (BR), salicylic acid (SA), and a commercial elicitor based on botanical extracts (BE) of Echinacea purpurea, Potentilla erecta, and Aloe vera on the physiological [stomatal conductance $\left(g_{\mathrm{S}}\right)$, leaf water potential $\left(\Psi_{\mathrm{wf}}\right)$, chlorophyll fluorescence, and growth] and biochemical [photosynthetic pigments, malondialdehyde (MDA) production, and proline content] responses of cape gooseberry plants subjected to a 6-day waterlogging period. The established treatments were as follows: 1) waterlogged plants without Foph; 2) waterlogged plants with Foph; 3) waterlogged, noninoculated $\left(\mathrm{Foph}^{-}\right)$plants treated foliarly with BR, SA, or BE; and 4) waterlogged, inoculated $\left(\mathrm{Foph}^{+}\right)$plants treated foliarly with BR, SA, or BE. The results showed that the foliar application of BR or $S A$ reduced vascular wilt development in plants subjected to a hypoxia period. In addition, three applications of BR, SA, or BE favored $g_{\mathrm{S}}, \Psi_{\mathrm{wf}}$, growth, and chlorophyll fluorescence parameters in cape gooseberry plants under the interaction between Foph and oxygen deficit in the soil. Also, higher photosynthetic pigment and proline contents were observed in plants treated with elicitors under stress combination, whereas a lower MDA production was evidenced in this group of plants. In conclusion, BR, SA, or BE can help mitigate the negative effects of the simultaneous occurrence of Foph and a waterlogging condition for 6 days in cape gooseberry plants.
\end{abstract}

Cape gooseberry ( $P$. peruviana L.) is an herbaceous plant from the South American Andes that belongs to the Solanaceae family. $P$. peruviana is the second exported fruit species in Colombia with an export value of US\$27.8 million during 2017 (ÁlvarezFlórez et al., 2017; Olivares-Tenorio et al., 2017). Also, this crop occupied 1023 ha with a production of $\approx 15,586 \mathrm{t}$ in 2017 (Agronet, 2019; Procolombia, 2019).

$P$. peruviana crop productivity has decreased in Colombia during recent years because of factors such as vascular wilt (Foph), abiotic stresses (waterlogging), and/ or the interaction between these factors (Aldana et al., 2014; Moreno-Velandia et al., 2019; Villarreal-Navarrete et al.,

Received for publication 12 Sept. 2019. Accepted for publication 21 Oct. 2019.

Published online 12 December 2019.

H.R.-D. is the corresponding author. E-mail: hrestrepod@ unal.edu.co.

This is an open access article distributed under the CC BY-NC-ND license (https://creativecommons. org/licenses/by-nc-nd/4.0/).
2017). Vascular wilt is the most limiting crop disease that has been reported in more than $50 \%$ of growing areas in the country, generating yield reductions or total crop loss (OsorioGuarín et al., 2016; Simbaqueba et al., 2018). Disease symptoms include marginal leaf chlorosis, vascular tissue browning, plant wilting, atrophy, and eventual death (Abdallah et al., 2016). Pathogen infection occurs by direct penetration and intracellular growth of hyphae through the root tip into the xylem vessels, causing plant wilting (Król et al., 2015). Disease management has been hampered by the resistance of the pathogen to commercial fungicides. In addition, the presence of chlamydospores allows the prolonged survival of the pathogen, which can infect roots of new plants (Król et al., 2015; Osorio-Guarín et al., 2016).

Crops are currently facing waterlogging conditions (hypoxia) because of high rainfall, inefficient irrigation practices, and/or inadequate soil drainage, generating growth and yield limitations (Herzog et al., 2016). Waterlogging stress can cause several types of physiological responses in plants and also can favor the incidence of diseases (Rao and Li, 2003). Short or moderate waterlogging periods can cause low root growth and dry matter accumulation, leaf senescence, plant wilting, and crop death $(\mathrm{Wu}$ et al., 2015). Leaf gas exchange properties ( $g_{\mathrm{S}}$, transpiration, and photosynthesis) and photosynthetic pigment content also are associated with the type of plant acclimation responses ( $\mathrm{Zhu}$ et al., 2016). In addition, MDA and proline production have been used as biochemical markers to characterize plant responses to abiotic and biotic stresses (Dar et al., 2016; Irulappan and Senthil-Kumar, 2018).

Chlorophyll fluorescence parameters also are affected by hypoxia conditions, and these parameters can be effective in detecting changes in the mechanisms involved in plant acclimation (He et al., 2018; Shao et al., 2013). A low electron transport rate (ETR), photochemical efficiency of photosystem II (PSII) $\left(\mathrm{F}_{\mathrm{v}} / \mathrm{F}_{\mathrm{m}}\right)$, photochemical quenching $(\mathrm{qP})$, and a high nonphotochemical quenching (NPQ) have been reported under waterlogging conditions (Liu et al., 2014; Wu et al., 2015). Moderate periods of hypoxia (6-8 d) also have caused a reduction in plant height, leaf area (LA), plant dry weight, and high plant wilting in cape gooseberry plants (Aldana et al., 2014).

Waterlogging also can increase plant diseases associated with soil pathogens, such as vascular wilt caused by $F$. oxysporum $\mathrm{f}$. sp. cubense in banana (Musa spp.) (Aguilar et al., 2000; Shivas et al., 1995), crown and root rot caused by Phytophthora spp. in apple (Malus $\times$ domestica Borkh.) and raspberry (Rubus idaeus L.) (Duncan and Kennedy, 1989; Wilcox, 1993), and damping-off caused by Pythium irregulare in beans (Phaseolus vulgaris L.) (Li et al., 2015b). This greater plant susceptibility to soilborne pathogens under waterlogging conditions is associated with the ability of microorganisms to grow in anaerobic conditions ( $\mathrm{Rao}$ and $\mathrm{Li}, 2003$ ). Regarding the combined stress effect (waterlogging and plant pathogen), Moslemi et al. (2018) observed greater basal leaf chlorosis, wilting, and necrosis in pyrethrum plants [Tanacetum cinerariifolium (Trev.) Schultz. Bip.] infected with Paraphoma vinacea, F. oxysporum, and Fusarium avenaceum exposed to waterlogging for $7 \mathrm{~d}$. Also, these authors reported that hypoxia conditions generated a lower plant biomass, and lower stem and flower number in pathogen-infected plants.

The use of synthetic elicitors can be considered an effective tool to mitigate the negative effects generated by abiotic and biotic stresses in plants (Llorens et al., 2017; Naik and Al-Khayri, 2016). Elicitors are chemical compounds that can be sprayed on leaves, causing a stimulus on plant defense mechanisms and secondary metabolite synthesis under abiotic and biotic stress conditions (Llorens et al., 2017; Ramírez-Godoy et al., 2018; Thakur and Sohal, 2013). SA, $\mathrm{BR}$, and plant BEs have been studied and characterized as compounds that activate plant defense mechanisms against stress conditions (abiotic and biotic) (Bektas and Eulgem, 2015; Singh et al., 2017; Vardhini 
and Anjum, 2015; Xue et al., 2013; Zhang et al., 2015).

SA acts as a signaling molecule modulating tolerance to stress through the activation or regulation of physiological, biochemical, and molecular processes (Bernal-Vicente et al., 2017; Khan et al., 2015). Foliar SA application decreased the size of the lesion generated by Phytophthora cinnamomi in lupin (Lupinus augustifolius) roots (Groves et al., 2015) and enhanced growth and physiological and biochemical behavior of tomato plants (Solanum lycopersicum L.) with waterlogging for $45 \mathrm{~d}$ (Singh et al., 2017).

BRs are polyhydroxylated steroidal plant hormones that also can help the tolerance to different abiotic and biotic stresses in plants (Anwar et al., 2018; Fariduddin et al., 2014). BR application decreased the negative effects generated by Verticillium dahliae in cotton plants (Gossypium hirsutum L.) (Bibi et al., 2014) and improved protein content, dry matter yield, nitrogen uptake, and harvest index in maize plants (Zea mays L.) with waterlogging for $10 \mathrm{~d}$ (Otie et al., 2019).

BEs also have been considered as an effective alternative for plant pathogen control and stress mitigation in recent years (Joseph et al., 2017; Van Oosten et al., 2017). Rongai et al. (2017) observed that BE from pomegranate (Punica granatum) peels showed antifungal activity on $F$. oxysporum f. sp. lycopersici in tomato plants $(S$. lycopersicum L.) under in vitro conditions. Elansary et al. (2017) also observed a positive effect of seaweed BE sprays on the physiological and biochemical traits of seashore paspalum (Paspalum vaginatum) plants subjected to water stress.

Foph management practices in cape gooseberry crops have been mainly based on the use of synthetic fungicides (MorenoVelandia et al., 2019); however, synthetic elicitors have been used as alternatives for soilborne pathogen management in recent years (McGovern, 2015). Studies about synthetic elicitors have been focused separately on disease control (Ding et al., 2009a; Mandal et al., 2009; Mostafa et al., 2018) or their effect on abiotic stress mitigation (Csiszár et al., 2018; Mansori et al., 2015; Rao and Dixon, 2017); however, the available literature on the use of these compounds to reduce the negative impact generated by combined stresses (pathogens and abiotic stresses) in Andean fruit trees, such as cape gooseberry, is still scarce. The present research hypothesizes that foliar BR, SA, or BE sprays can help to mitigate the negative effects caused by these two stresses (Foph and waterlogging) by enhancing physiological $\left(g_{\mathrm{S}}, \Psi_{\mathrm{wf}}\right.$, chlorophyll fluorescence parameters, and growth) and biochemical (proline, MDA, and photosynthetic pigments) responses in cape gooseberry plants.

\section{Materials and Methods}

Growth conditions and pathogen inoculation. An experiment was carried out from Sept. 2018 to Jan. 2019 under greenhouse condi-
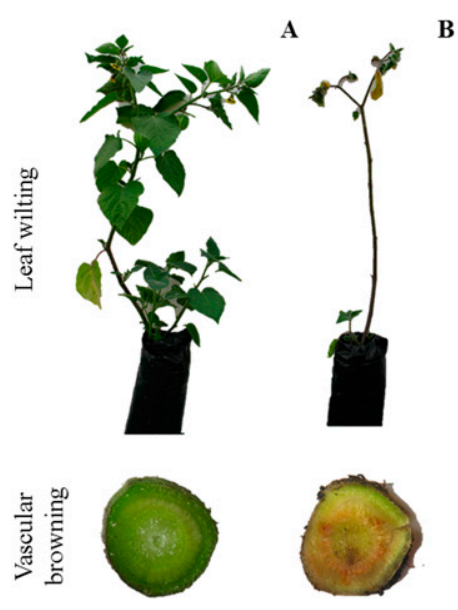

B

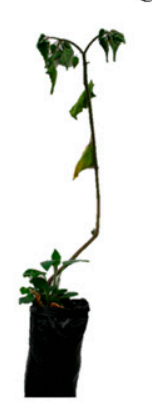

C

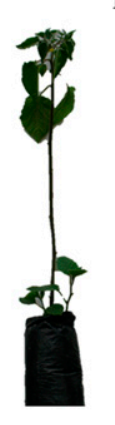

D

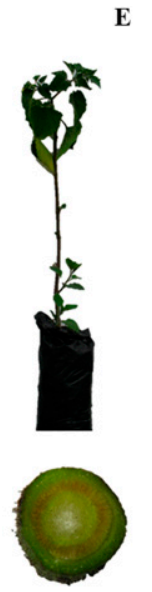

$\mathbf{E}$

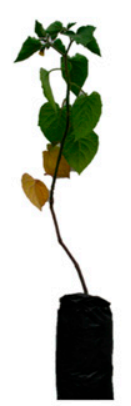

Fig. 1. Leaf wilting and vascular browning of cape gooseberry plants with and without Fusarium oxysporum f. sp. physali (Foph) inoculation under waterlogging conditions. Control plants (A), inoculated plants with waterlogging $(\mathbf{B})$, inoculated plants without waterlogging $(\mathbf{C})$, inoculated plants with waterlogging and botanicals extracts application (D), inoculated plants with waterlogging and salicylic acid application (E), and inoculated plants with waterlogging and brassinosteroids application (F).

Table 1. Area under the disease progress curve (AUDPC) and severity index of vascular wilt caused by Fusarium oxysporum f. sp. physali (Foph) in cape gooseberry plants under conditions of hypoxia in the soil and sprayed with synthetic elicitors [brassinosteroids (BR), salicylic acid (SA), or botanical extracts (BE) of Echinacea purpurea, Potentilla erecta, and Aloe vera] at $51 \mathrm{~d}$ after inoculation.

\begin{tabular}{lcc}
\hline Treatment & AUDPC & Severity index of vascular wilt \\
\hline No waterlogging + Foph & $76.36 \mathrm{a}^{\mathrm{z}}$ & $3.71 \mathrm{ab}$ \\
Waterlogging + Foph & $80.13 \mathrm{a}$ & $4.21 \mathrm{a}$ \\
BR $^{\mathrm{y}}$ & $45.73 \mathrm{c}$ & $2.82 \mathrm{~d}$ \\
SA & $52.93 \mathrm{bc}$ & $3.02 \mathrm{~cd}$ \\
BE & $68.15 \mathrm{ab}$ & $3.49 \mathrm{bc}$ \\
Significance & $* * *$ & $* * *$ \\
CV (\%) & 12.68 & 8.71 \\
\hline
\end{tabular}

${ }^{\mathrm{z}}$ Values within a column followed by different letters are significantly different at $P \leq 0.05$ according to the Tukey test.

${ }_{\mathrm{y}}^{\mathrm{y}}$ Foph-inoculated cape gooseberry plants under waterlogging conditions and sprayed with three different synthetic elicitors (BR, SA, and BE of E. purpurea, P. erecta, and A. vera).

$\mathrm{CV}=$ coefficient of variation.

*** Significant at $P \leq 0.001$.

tions at the Faculty of Agricultural Sciences of the Universidad Nacional de Colombia, Bogotá (lat. $4^{\circ} 35^{\prime} 56^{\prime \prime} \mathrm{N}$, long. $74^{\circ} 04^{\prime} 51^{\prime \prime} \mathrm{W}$, altitude $2557 \mathrm{~m}$ above sea level). The general environmental conditions during the experiment were as follows: natural photoperiod of $12 \mathrm{~h}$ (photosynthetically active radiation of $1500 \mu \mathrm{mol} \cdot \mathrm{m}^{-2} \cdot \mathrm{s}^{-1}$ at noon), $\approx 65 \%$ relative humidity, $28.4 / 12.5{ }^{\circ} \mathrm{C}$ day/night temperature, and $20.5^{\circ} \mathrm{C}$ average temperature. Twomonth-old ecotype 'Colombia' ( $P$. peruviana L.) seedlings purchased from a local nursery were used. To rule out $F$. oxysporum infection, the plants were previously indexed using the methodology described by Leslie and Summerell (2006). Then, seedlings were subjected to an acclimation period for $15 \mathrm{~d}$. When plants developed between three and four true leaves, they were transplanted into 2-L plastic pots, containing a soil-based substrate (clay loam) and rice husk (3:1 v/ v) with and without Foph inoculum. Before substrate inoculation, the methodology described by Park (1961) was used to confirm Foph absence in the soil used for the substrate mixture.
Substrate inoculation was performed by adding $100 \mathrm{~mL}$ of a liquid Foph suspension at a concentration of $1 \times 10^{6}$ microconidia $/ \mathrm{mL}$ per $0.9 \mathrm{~kg}$ of substrate (soil + rice husk), guaranteeing a final concentration of $1 \times 10^{4}$ microconidia/g of substrate (Osorio-Guarín et al., 2016). Finally, two inoculation conditions were obtained (with and without Foph presence). The Foph-Map5 strain supplied by the Biological Control Laboratory of the Corporación Colombiana de Investigación Agropecuaria (Agrosavia, Mosquera, Colombia) was used as a source of pathogen inoculum in the present experiment. Young mycelium segments of the supplied strain were cultured in $50 \mathrm{~mL}$ potato dextrose broth (Difco, Becton Dickinson, Sparks, MD) in 250-mL Erlenmeyer flasks and incubated for $7 \mathrm{~d}$ with constant agitation in an orbital shaker (Laboratory-Line, Melrose Park, IL) at $125 \mathrm{rpm}$ and $28{ }^{\circ} \mathrm{C}$ under dark conditions (MorenoVelandia et al., 2019).

Seedlings were irrigated daily with $50 \mathrm{~mL}$ of a nutrient solution prepared from a complete liquid fertilizer (Nutriponic; Walco SA, Bogotá, Colombia) at a dose of $5 \mathrm{~mL} \cdot \mathrm{L}^{-1} \mathrm{H}_{2} \mathrm{O}$ 


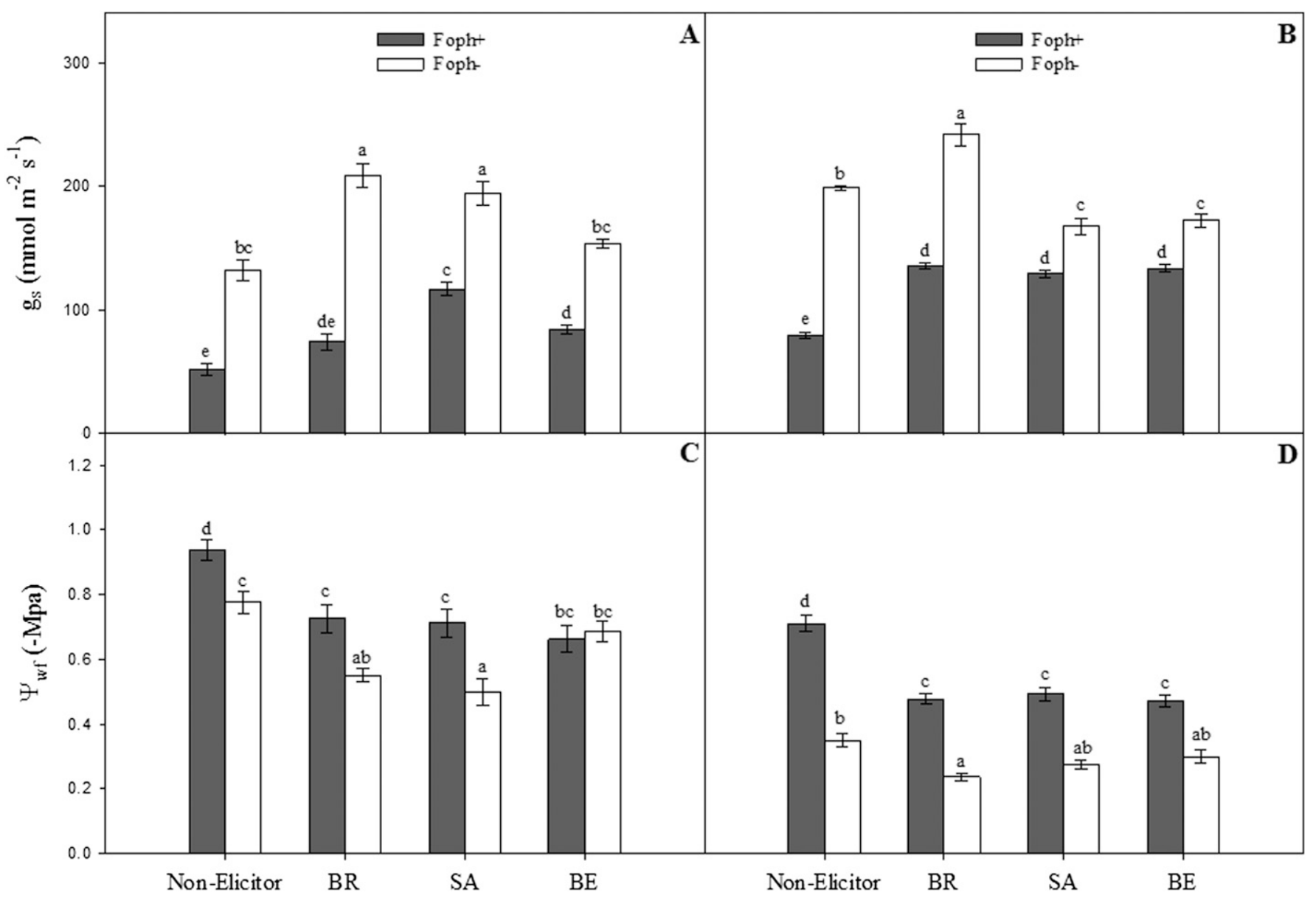

Fig. 2. Effect of synthetic elicitor [brassinosteroids (BR), salicylic acid (SA), or botanical extracts (BE) of Echinacea purpurea, Potentilla erecta, and Aloe vera] sprays on the stomatal conductance $\left(g_{\mathrm{S}}\right)$ and water potential $\left(\Psi_{\mathrm{wf}}\right)$ of cape gooseberry plants at $11(\mathbf{A}, \mathbf{C})$ and $51(\mathbf{B}, \mathbf{D})$ days after inoculation (DAI) with (gray bars) and without (white bars) Fusarium oxysporum f. sp. physali (Foph) subjected to a short waterlogging period (6 d). Data represent the average of five plants \pm SE per treatment $(n=5)$. Bars followed by different letters indicate statistically significant differences according to the Tukey test $(P \leq 0.05)$.

from transplanting to the beginning of the waterlogging periods, and later from the end of the natural drainage to the end of the experiment. The concentration of the nutrient solution was as follows: $2.08 \mathrm{~mm} \mathrm{Ca}\left(\mathrm{NO}_{3}\right)_{2} \cdot 4$ $\mathrm{H}_{2} \mathrm{O}, 1.99 \mathrm{~mm} \mathrm{MgSO}_{4} \cdot 7 \mathrm{H}_{2} \mathrm{O}, 2.00 \mathrm{~mm}$ $\mathrm{NH}_{4} \mathrm{H}_{2} \mathrm{PO}_{4}, 10.09 \mathrm{~mm} \mathrm{KNO}_{3}, 46.26 \mathrm{nM}$ $\mathrm{H}_{3} \mathrm{BO}_{3}, 0.45 \mathrm{nM} \mathrm{Na} \mathrm{MoO}_{4} \cdot 2 \mathrm{H}_{2} \mathrm{O}, 0.32$ $\mathrm{nM} \mathrm{CuSO} \cdot .5 \mathrm{H}_{2} \mathrm{O}, 9.19 \mathrm{nM} \mathrm{MnCl}_{2} \cdot 4 \mathrm{H}_{2} \mathrm{O}$, $0.76 \mathrm{nM} \mathrm{ZnSO} \cdot 7 \mathrm{H}_{2} \mathrm{O}$, and $19.75 \mathrm{nM}$ $\mathrm{FeSO}_{4} \cdot \mathrm{H}_{2} \mathrm{O}$. The water volume used was obtained by daily quantification of the evapotranspiration needs of the plants by means of the gravimetric technique described by Hainaut et al. (2016).

Waterlogging and synthetic elicitor treatments. At the time of transplantation, two groups of 40 plants each were obtained: the first group consisted of seedlings planted in substrate with Foph (inoculated), and the second corresponded to seedlings planted in substrate without Foph (noninoculated). Then, the two groups were subjected to a waterlogging period of 6 consecutive $d$. The stress condition due to waterlogging was imposed by placing the seedlings inside 120 -L plastic boxes, to which $60 \mathrm{~L}$ tap water was added to guarantee a $5-\mathrm{cm}$ level on the base of the stem $5 \mathrm{~d}$ after inoculation (DAI). At the end of the waterlogging period (11 DAI), the seedlings were removed from this condition and natural drainage was allowed until reaching the field capacity in the substrate (18 DAI). Afterward, the seedlings were maintained under normal irrigation conditions until the end of the experiment (51 DAI).

A group of 10 plants was selected to be sprayed with SA, BR, or BE (a commercial product based on E. purpurea, $P$. erecta, and $A$. vera extracts). The doses of each synthetic elicitor were $100 \mathrm{ppm}, 1 \mathrm{ppm}$, and $2.5 \mathrm{~mL}$ of the commercial product per liter of $\mathrm{H}_{2} \mathrm{O}$, respectively. Eight different groups of treatments were obtained depending on Foph inoculation, waterlogging condition, and synthetic elicitor spray, which are summarized as follows: 1) waterlogged plants without Foph; 2) waterlogged plants with Foph; 3) waterlogged, noninoculated $\left(\mathrm{Foph}^{-}\right)$plants sprayed with BR, SA, or BE; and 4) waterlogged, inoculated $\left(\mathrm{Foph}^{+}\right)$plants sprayed with BR, SA, or BE. Likewise, two additional groups with and without Foph inoculation, without waterlogging, and without synthetic elicitors sprays were established as absolute control $\left(\mathrm{Foph}^{-}\right)$and pathogen control $\left(\mathrm{Foph}^{+}\right)$. The general characteristics of the synthetic elicitors are presented as follows: SA (2-
Hydroxybenzoic acid; Panreac Applichem, Barcelona, Spain); Biomex DI-31 [(25 R) $3 \beta, 5 \alpha$-dihydroxy-spirostan-6-one; Minerales exclusivos SA, Bogotá, Colombia]; Loker ( $E$. purpurea, $P$. erecta, and $A$. vera extracts, $\mathrm{K}$ and $\mathrm{Mg}$ salts; Biolchim S. p. A., Medicina, Bologna, Italy).

Foliar synthetic elicitor applications were performed at three different times during the experiment: 1) foliar application $8 \mathrm{~d}$ before inoculation, 2) foliar application at the time of inoculation, and 3 ) foliar application 8 DAI. In general, each synthetic elicitor spray was carried out between 0700 and $0900 \mathrm{HR}$, using a 1.8-L manual spray pump (Royal Condor Garden, Soacha, Colombia) with an application volume of $20 \mathrm{~mL} \mathrm{H}_{2} \mathrm{O}$ per plant, wetting the upper and lower leaf surfaces. A coadjuvant [Tween 20 (Merck, Darmstadt, Germany)] was used at a rate of $0.02 \%(\mathrm{v} / \mathrm{v})$ in all foliar applications. Control plants were sprayed with distilled water and the adjuvant at the same concentration. The length of the waterlogging period, number of foliar applications, and doses used for each elicitor were determined from previous studies (Chávez-Arias et al., 2019). A total of 10 treatment groups were obtained and 

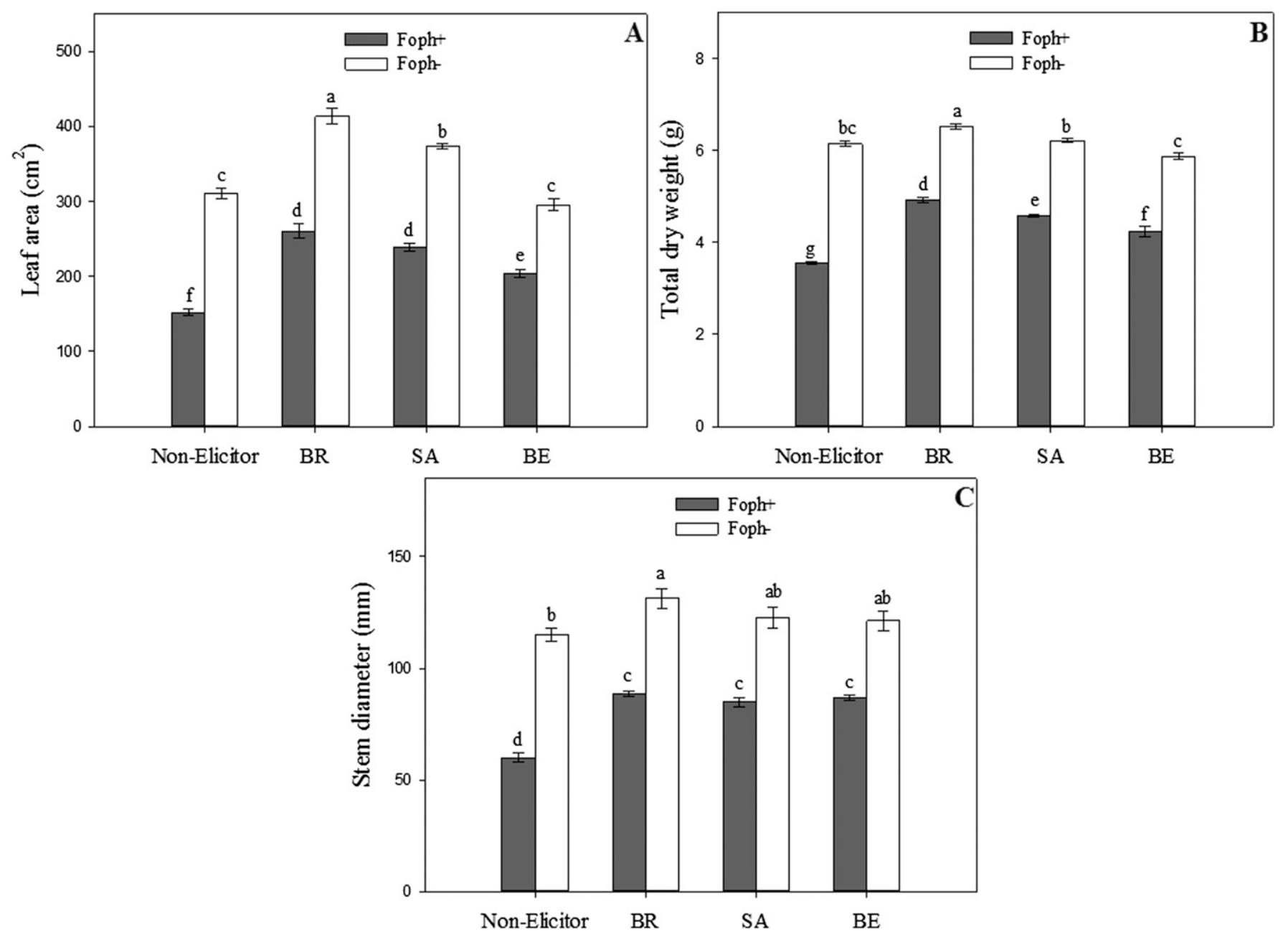

Fig. 3. Effect of synthetic elicitor [brassinosteroids (BR), salicylic acid (SA), or botanical extracts (BE) of Echinacea purpurea, Potentilla erecta, and Aloe vera] sprays on leaf area (LA) (A), total dry weight (TDW) (B), and stem diameter (SD) (C) of cape gooseberry plants with (gray bars) and without (white bars) Fusarium oxysporum f. sp. physali (Foph) subjected to a short waterlogging period (6 d) at $51 \mathrm{~d}$ after inoculation (DAI). Data represent the average of five plants \pm SE per treatment $(\mathrm{n}=5)$. Bars followed by different letters indicate statistically significant differences according to the Tukey test $(P \leq 0.05)$.

arranged in a completely randomized design in which each treatment consisted of 10 plants (repetitions). Finally, the experiment lasted $74 \mathrm{~d}$.

Analysis of vascular wilt severity. Vascular wilt severity was determined from the beginning of the waterlogging period (5 DAI) to the end of the experiment (51 DAI). Severity was estimated through visual assessments of the characteristic symptoms of the disease every $3 \mathrm{~d}$. To perform the evaluation, the scale described by Moreno-Velandia (2017) was followed: 0) asymptomatic plants; 1) slight epinastic response and mild chlorosis of the lower third of the plant; 2) epinastic response in $30 \%$ to $50 \%$ of the leaves and moderate chlorosis in mature leaves; 3) epinastic response in $60 \%$ to $80 \%$ of the leaves and moderate chlorosis in the middle third; 4) epinastic response in all the leaves of the plant, severe chlorosis and defoliation; and 5) wilting, severe defoliation, and/or dead plant. The disease severity index can be used to indicate plant performance to compare treatment effectiveness (in this case, synthetic elicitor application) to reduce disease. The disease severity index was calculated using Eq. [1], described by Chiang et al. (2017).

Disease severity index $=\left(\sum(n v) / V\right)$,

where $n$ is the level of infection according to the scale, $v$ is the number of plants present in each level, and $V$ is the total number of evaluated plants.

Afterward, disease intensity was analyzed by calculating the area under the disease progress curve (AUDPC), which is a useful quantitative summary of disease intensity over time, for comparison across management tactics (in this case, foliar application of synthetic elicitors). The AUDPC was estimated in each treatment by the trapezoidal integration method shown in Eq. [2] (Alves et al., 2017; Campbell and Madden, 1990):

$\operatorname{AUDPC}=\left\{\sum_{i=1}^{n-1}\left[\left(y_{i}+y_{i+1}\right) / 2\right] *\left(t_{i+1}-t_{i}\right)\right\}$,

where $n$ is the number of evaluations, $y_{i}$ and $y_{i+1}$ are the values of the severity scale at evaluation time, and $\left(t_{i+1}-t_{i}\right)$ is the time interval between evaluations.

Finally, pathogen presence or absence in Foph-inoculated and noninoculated plants was confirmed by isolates in potato dextrose agar (PDA) medium (Oxoid, Basingstoke, UK) from explants taken from the base of the stem at each evaluation time (11 and 51 DAI) (Leslie and Summerell, 2006).

$\mathrm{g}_{S}$ and $\Psi_{w f} g_{\mathrm{S}}$ and $\Psi_{\mathrm{wf}}$ were estimated on the fourth fully expanded leaf from the upper portion of the canopy. A steady-state porometer (SC-1; Decagon Devices Inc., Pullman, WA) was used to estimate $g_{\mathrm{S}}$. Then, $\Psi_{\mathrm{wf}}$ was measured with a Scholander pressure chamber (Model 615; PMS, Corvallis, OR) on the same leaf used to estimate $g_{\mathrm{S}}$ on completely sunny days at 11 and 51 DAI between 0900 and $1200 \mathrm{HR}$.

Chlorophyll fluorescence parameters. The same leaves used to estimate $g_{\mathrm{S}}$ were used for the measurement of maximum quantum yield of PSII $\left(\mathrm{F}_{\mathrm{v}} / \mathrm{F}_{\mathrm{m}}\right), \mathrm{qP}, \mathrm{NPQ}$, and ETR using a modulated fluorometer (MINI-PAM; Walz, Effeltrich, Germany). Before taking the measurements, leaves were adapted to darkness using the fluorometer's clips for 10 

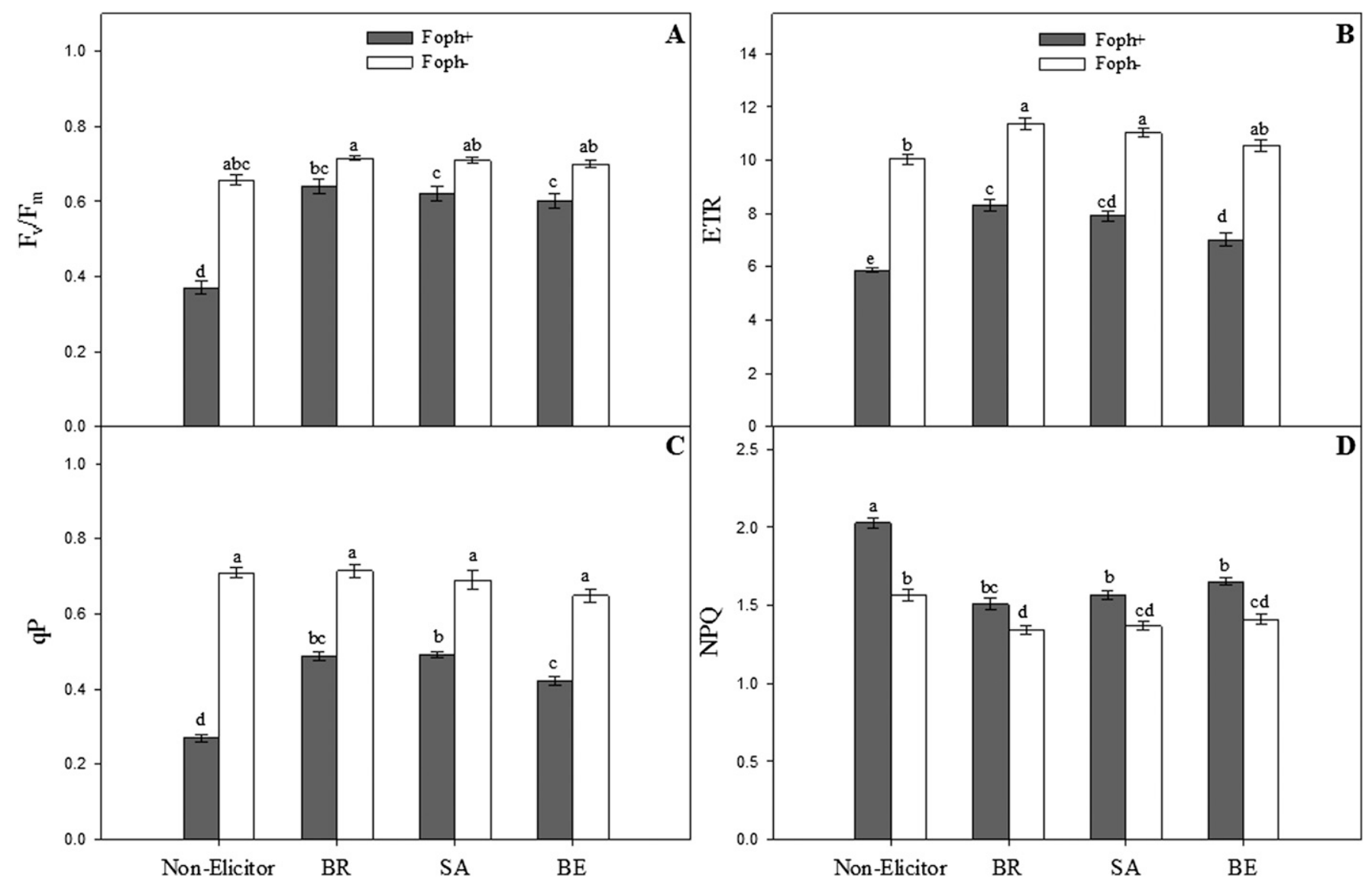

Fig. 4. Effect of synthetic elicitor [brassinosteroids (BR), salicylic acid (SA), or botanical extracts (BE) of Echinacea purpurea, Potentilla erecta, and Aloe vera] sprays on maximum photochemical efficiency of PSII $\left(\mathrm{F}_{\mathrm{v}} / \mathrm{F}_{\mathrm{m}}\right)(\mathbf{A})$, electron transport rate (ETR) (B), photochemical quenching (qP) $(\mathbf{C})$, and nonphotochemical quenching (NPQ) (D) of cape gooseberry plants with (gray bars) and without (white bars) Fusarium oxysporum f. sp. physali (Foph) subjected to a short waterlogging period ( $6 \mathrm{~d})$ at $51 \mathrm{~d}$ after inoculation (DAI). Data represent the average of five plants \pm SE per treatment $(\mathrm{n}=5)$. Bars followed by different letters indicate statistically significant differences according to the Tukey test $(P \leq 0.05)$.

$\min$. Then, leaves received a pulse of actinic light of up to $2600 \mu \mathrm{mol} \cdot \mathrm{m}^{-2} \cdot \mathrm{s}^{-1}$ on their surface to obtain the fluorescence parameters. These measurements were also taken at 11 at 51 DAI.

Growth parameters. Leaves, stems, and roots of each plant per treatment were collected separately at 11 and 51 DAI and dried in a compressed dry air oven (Model 27; Thelco, Chicago, IL) at $80{ }^{\circ} \mathrm{C}$ for $48 \mathrm{~h}$ to estimate their dry weight. The stem diameter for each treatment was estimated using a caliper and LA was obtained from digital images in TIFF (Tagged Image File Format) format using a digital camera (D3300; Nikon, Bangkok, Thailand). Images were analyzed using a Java image processing program (Image J; National Institute of Mental Health, Bethesda, MD). Based on the total dry weight (TDW) of the plants from all the treatments, the relative tolerance index (RTI) was estimated according to Eq. [3] (Dutta Gupta et al., 1995; Roussos et al., 2010).

RTI $=\left(\frac{\text { Total biomass under the interaction Foph } \times \text { waterlogging }}{\text { Total biomass of plants without stress }}\right) \times 100$

Leaf photosynthetic pigments. The equations described by Wellburn (1994) were used to estimate total chlorophyll (TChl) and carotenoid $(\mathrm{Cx}+\mathrm{c})$ contents. Leaf samples of $30 \mathrm{mg}$ from the middle third of the canopy were collected and then homogenized in $3 \mathrm{~mL}$ of $80 \%$ acetone. Then, the samples were centrifuged (centrifuge model 420101; Becton Dickinson Primary Care Diagnostics, Sparks, MD) at $5000 \mathrm{rpm}$ for $10 \mathrm{~min}$ to remove particles. The supernatant was diluted to a final volume of $6 \mathrm{~mL}$ by adding acetone (Sims and Gamon, 2002). Chlorophyll content was determined at 663 and 646 $\mathrm{nm}$, and carotenoids were measured at $470 \mathrm{~nm}$ using a spectrophotometer (Spectronic BioMate 3 ultraviolet-vis; Thermo, Madison, WI).

Proline and MDA content. The method described by Bates et al. (1973) was used to estimate proline content in each evaluated treatment. Samples of $300 \mathrm{mg}$ from leaves of the middle third of the canopy were homogenized in liquid nitrogen and stored for further analysis. Then, $10 \mathrm{~mL}$ of a $3 \%$ aqueous sulfosalicylic acid solution was added to the stored samples, which were filtered through Whatman paper (No. 2); $2 \mathrm{~mL}$ of this filtrate was reacted with $2 \mathrm{~mL}$ of ninhydrin acid and 2 $\mathrm{mL}$ of glacial acetic acid. The mixture was placed in a water bath at $90^{\circ} \mathrm{C}$ for $1 \mathrm{~h}$, and the reaction was stopped by incubation in ice. The resulting solution was dissolved in $4 \mathrm{~mL}$ toluene, and test tubes were shaken using a vortex shaker (V-1; BOECO, Hamburg, Germany). Finally, the absorbance readings were determined at $520 \mathrm{~nm}$ with the spectrophotometer. Proline content was calculated using the fresh weight of the sample with a standard calibration curve, as in Eq. [4].

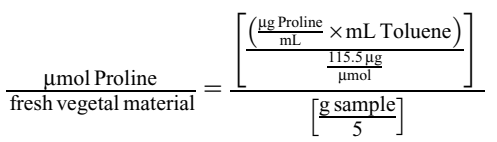

The thiobarbituric acid method described by Hodges et al. (1999) was used to estimate membrane lipid peroxidation (MDA). Leaf samples of $300 \mathrm{mg}$ from the middle third of the canopy of plants from the different treatments were macerated and stored in liquid nitrogen. Samples were centrifuged at $5000 \mathrm{rpm}$ for $10 \mathrm{~min}$ and their absorbances were estimated at 440,532, and $600 \mathrm{~nm}$ with the spectrophotometer. Finally, an extinction coefficient $\left(157 \mathrm{M} \cdot \mathrm{mL}^{-1}\right)$ was used to obtain the MDA concentration. Proline and MDA were measured at 51 DAI.

Experimental design and data analysis. Data were analyzed by a factorial arrangement with inoculation with the pathogen (with and without Foph) as the first factor, and synthetic elicitors (SA, BR, or BE) as the second factor. Each treatment group consisted of 10 plants. A principal components analysis was performed using the InfoStat 

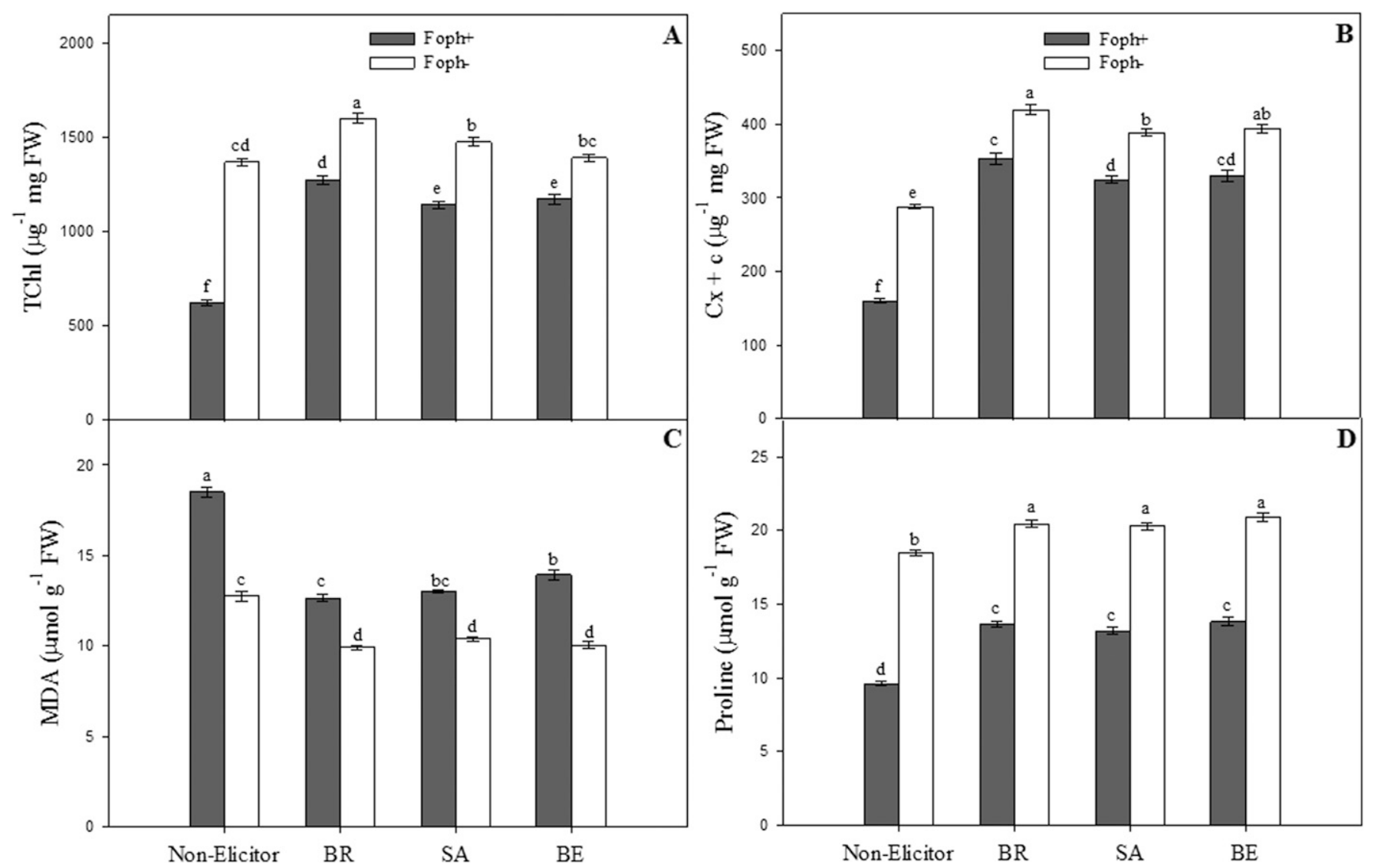

Fig. 5. Effect of synthetic elicitor [brassinosteroids (BR), salicylic acid (SA), or botanical extracts (BE) of Echinacea purpurea, Potentilla erecta, and Aloe vera] sprays on total chlorophyll content $(\mathrm{TChl})(\mathbf{A})$, carotenoids $(\mathrm{Cx}+\mathrm{c})(\mathbf{B})$, malondialdehyde production (MDA) (C), and leaf proline content $(\mathbf{D})$ of cape gooseberry plants with (gray bars) and without (white bars) Fusarium oxysporum $\mathrm{f}$. sp. physali (Foph) subjected to a short waterlogging period (6 d) at $51 \mathrm{~d}$ after inoculation (DAI). Data represent the average of five plants \pm SE per treatment $(\mathrm{n}=5)$. Bars followed by different letters indicate statistically significant differences according to the Tukey test $(P \leq 0.05)$. $\mathrm{FW}=$ fresh weight.

2016 program (analytical software; Universidad Nacional de Cordoba, Córdoba, Argentina) to select the best synthetic elicitors under the interaction between waterlogging and $F$. oxysporum f. sp. physali (Foph) inoculation. Then, the selected treatments were compared with the absolute control $\left(\mathrm{Foph}^{-}\right)$and pathogen control $\left(\mathrm{Foph}^{+}\right)$ through a completely randomized analysis. An analysis of variance was performed in all cases, and when significant differences $(P \leq$ 0.05 ) were found, a Tukey post hoc test was used for means comparison. The percentage values were transformed using the arcsine function. Data were analyzed using the Statistix v 9.0 software (Analytical Software, Tallahassee, FL). The figures and cluster analysis were carried out using the software SigmaPlot (version 12.0; Systat Software, San Jose, CA).

\section{Results}

Vascular wilt severity expressed as AUDPC and disease index. The evaluation of the AUDPC and vascular wilt index showed differences at $P \leq 0.001$ between plants of all Foph-inoculated treatments at 51 DAI. Foph presence was confirmed by isolates in PDA from affected material (Fig. 1). The pathogen was not isolated from plants without inoculation, without any synthetic elicitor sprays, without any stress, or from plants with only waterlogging (Fig. 1A).

The highest AUDPC values were obtained in inoculated plants with and without waterlogging, and with no synthetic elicitor sprays ( 80.13 and 76.36 , respectively) at the end of the experiment (51 DAI), which may show a higher vascular wilt progress (Table 1; Fig. 1B and C). An intermediate development of the disease was observed in plants with Foph, under waterlogging, and sprayed with $\mathrm{BE}$ (68.15), whereas plants with exogenous SA (52.93) and BR (45.73) applications showed the lowest levels of the disease (Table 1; Fig. 1D-F). Trends similar to those obtained in the AUDPC were observed on the vascular wilt index (Table 1).

$g_{S}$ and $\Psi_{w f}$. Differences were also found on $g_{\mathrm{S}}$ in the interaction between Foph inoculation and synthetic elicitors at $11(P=$ $0.0002)$ and 51 DAI $(P=0.0000)$ in plants under waterlogging conditions. In general, Foph presence caused a greater $g_{S}$ reduction in both sampling points. At $11 \mathrm{DAI}$, foliar sprays, mainly with BR or SA, obtained the highest $g_{\mathrm{S}}$ values $\left(208.9\right.$ and $194.3 \mathrm{mmol} \cdot \mathrm{m}^{-2} \cdot \mathrm{s}^{-1}$, respectively) under waterlogging conditions in nondiseased plants. On the other hand, it was observed that SA sprays favored a higher $g_{\mathrm{S}}\left(116.8 \mathrm{mmol} \cdot \mathrm{m}^{-2} \cdot \mathrm{s}^{-1}\right)$ only in Fophinoculated cape gooseberry plants and subjected to hypoxia in the soil (Fig. 2A). At 51
DAI, the plants without pathogen presence continued recording the highest $g_{\mathrm{S}}$ values. In these plants, foliar BR sprays increased this variable under oxygen deficit in the soil $\left(241.7 \mathrm{mmol} \cdot \mathrm{m}^{-2} \cdot \mathrm{s}^{-1}\right)$. A positive effect on $g_{\mathrm{S}}$ was evidenced when the inoculated plants were treated with $\mathrm{BR}, \mathrm{SA}$, or $\mathrm{BE}(\approx 132.9$ $\left.\mathrm{mmol} \cdot \mathrm{m}^{-2} \cdot \mathrm{s}^{-1}\right)$ compared with diseased plants, with no synthetic elicitor sprays and under waterlogging conditions $\left(79.2 \mathrm{mmol} \cdot \mathrm{m}^{-2} \cdot \mathrm{s}^{-1}\right)$ (Fig. 2B). Differences between the evaluated factors (presence of the pathogen and synthetic elicitors) were also recorded on $\Psi_{\mathrm{wf}}$ at 11 and $51 \mathrm{DAI}(P=0.0328$ and 0.0000 , respectively) in waterlogged cape gooseberry plants. Foph presence in waterlogged cape gooseberry plants generated more negative $\Psi_{\text {wf }}$ values at both sampling moments. At $11 \mathrm{DAI}, \mathrm{SA}$ or BR sprays favored the water status of noninoculated plants through a higher $\Psi_{\mathrm{wf}}$ under hypoxia conditions ( $\approx-0.53 \mathrm{Mpa}$ ) (Fig. $2 \mathrm{C}$ ).

On the other hand, foliar BR, SA, or BE sprays had a positive effect on $\Psi_{\mathrm{wf}}(\approx-0.74$ Mpa) in Foph-inoculated cape gooseberry plants and subjected to hypoxia conditions in the soil (Fig. 2C). At 51 DAI, noninoculated plants and with BR sprays showed a slight increase in $\Psi_{\text {wf }}$ values $(-0.22 \mathrm{Mpa})$ under waterlogging conditions. Likewise, foliar BR, SA, or BE sprays under oxygen deficiency in the soil caused an increase of $\Psi_{\text {wf }}$ in Foph-inoculated plants $(\approx-0.48 \mathrm{Mpa})$ 

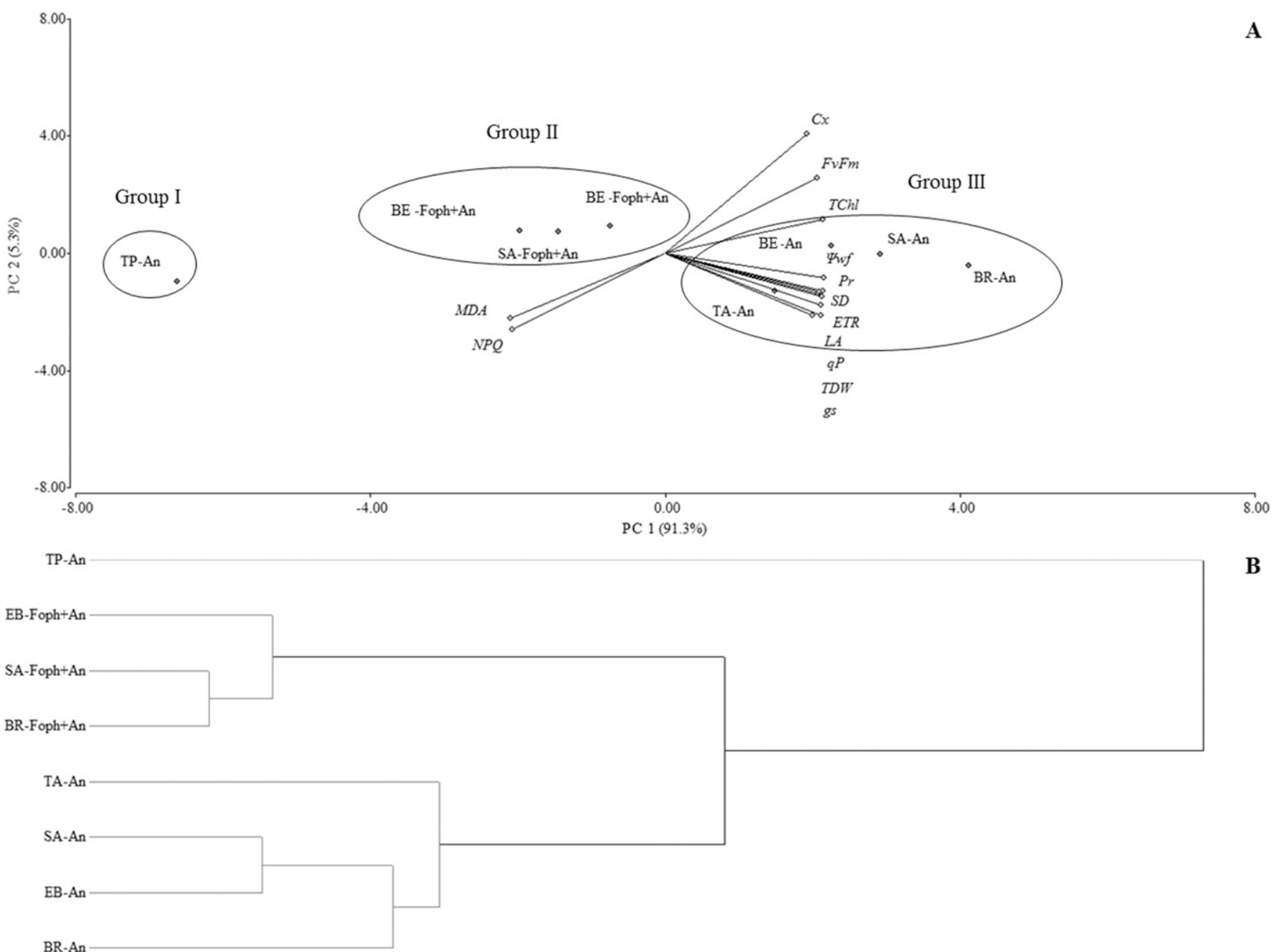

\begin{tabular}{llll}
\hline 0.00 & 2.02 & 4.04 & 6.06
\end{tabular}

Fig. 6. Effect of the interaction between Fusarium oxysporum f. sp. physali (Foph) inoculation and synthetic elicitor [brassinosteroids (BR), salicylic acid (SA), or botanical extracts (BE) of Echinacea purpurea, Potentilla erecta, and Aloe vera] sprays on the biplot analysis (A) and dendogram using Euclidean distance (B) of cape gooseberry plants subjected to a short waterlogging period $(6 \mathrm{~d})$ at $51 \mathrm{~d}$ after inoculation (DAI). TA = noninoculated plants without any synthetic elicitor spray; TP = Foph-inoculated plants without any synthetic elicitor spray; An = plants subjected to a short waterlogging period $(6 \mathrm{~d})$; $\mathrm{BR}=$ plants with three foliar brassinosteroid applications; $\mathrm{SA}=$ plants with three foliar salicylic acid applications; $\mathrm{BE}=$ plants with three foliar botanical extract applications; $\mathrm{DWT}=$ dry weight total; $\mathrm{LA}=$ leaf area; $\mathrm{SD}=$ stem diameter; $\mathrm{Pr}=$ proline; $\mathrm{TChl}=$ total chlorophyll $\mathrm{Cx}=$ carotenoids; $\mathrm{MDA}=$ malondialdehyde; $\mathrm{qP}=$ photochemical quenching; $\mathrm{NPQ}=$ nonphotochemical quenching; $\mathrm{F}_{\mathrm{v}} / \mathrm{F}_{\mathrm{m}}=$ photochemical efficiency of PSII; ETR = electron transport rate; $g_{\mathrm{S}}=$ stomatal conductance; $\Psi_{\mathrm{wf}}=$ leaf water potential; $\mathrm{PC}=$ principal component.

compared with diseased and untreated plants (-0.71 Mpa) (Fig. 2D).

Plant growth variables. Growth parameters (LA, TDW, and stem diameter) of cape gooseberry plants subjected to hypoxia showed differences $(P=0.0002,0.0000$, and 0.0164 , respectively) in the interaction between Foph presence and synthetic elicitors at $51 \mathrm{DAI}$. In general, the group of plants without Foph showed the highest growth parameters compared with inoculated plants under waterlogging conditions (Fig. 3). Foliar BR, SA, or BE sprays favored LA in Foph-inoculated plants (BR $260.1 \mathrm{~cm}^{2}$, SA $238.8 \mathrm{~cm}^{2}$, and BE $204.4 \mathrm{~cm}^{2}$ ) under waterlogging conditions. In addition, foliar BR and SA sprays enhanced the same variable in noninoculated (BR $413.2 \mathrm{~cm}^{2}$ and SA 373.3 $\mathrm{cm}^{2}$ ) plants under soil oxygen deficiency (Fig. 3A). The TDW of cape gooseberry plants subjected to hypoxia in the soil was mainly favored in the treatment with BR sprays in both situations of pathogen inoculation (with and without Foph) (4.93 and 6.52 $\mathrm{g}$, respectively). However, $\mathrm{SA}$ and $\mathrm{BE}$ favored this variable in inoculated cape gooseberry plants under hypoxia (Fig. 3B). Finally, foliar BR, SA, or BE sprays also produced an increase in stem diameter values in plants with and without Foph presence under the condition of oxygen deficit in the soil (Fig. 3C).

Chlorophyll a fluorescence parameters. Significant differences were observed between Foph inoculation and synthetic elicitor sprays on the chlorophyll $a$ fluorescence parameters (Fv/Fm, ETR, qP, and NPQ) of cape gooseberry plants under waterlogging conditions at 51 DAI. Foph inoculation caused lower values of the Fv/Fm ratio,
$\mathrm{ETR}$, and qP of cape gooseberry plants under waterlogging conditions; however, an opposite trend was obtained with NPQ for these same plants (Fig. 4). BR, SA, or BE sprays showed two effects on the fluorescence parameters in cape gooseberry plants with waterlogging and without Foph. In the first case, the use of synthetic elicitors did not cause any differences on $\mathrm{Fv} / \mathrm{Fm}$ and $\mathrm{qP}$ (Fig. 4A and $\mathrm{C}$ ); in the second case, the application of these elicitors generated higher ETR $(\approx 10.9)$ and lower NPQ $(\approx 1.38)$ values (Fig. 4B and D). On the other hand, Fophinoculated plants under waterlogging showed an increase in the parameters $\mathrm{Fv} / \mathrm{Fm}(\approx 0.62)$, $\operatorname{ETR}(\approx 7.71)$, and $\mathrm{qP}(\approx 0.47)$ after the foliar treatment with $\mathrm{BR}, \mathrm{SA}$, or BE compared with inoculated plants subjected to waterlogging and without any elicitor application $(0.37$, 5.87, and 0.27 for $\mathrm{Fv} / \mathrm{Fm}, \mathrm{ETR}$, and $\mathrm{qP}$, 
respectively) (Fig. 4A-C). In contrast, a decrease in NPQ values was registered with the use of synthetic elicitors $(\approx 1.58)$ compared with diseased, waterlogged, and untreated plants (2.03) (Fig. 4D).

Leaf photosynthetic pigments. Figure 5 shows the content of leaf photosynthetic pigments (TChl and $\mathrm{Cx}+\mathrm{c})$. Differences $(P=$ $0.0000)$ were found in the photosynthetic pigment content between the evaluated factors (Foph presence $\times$ synthetic elicitors) at the end of the experiment (51 DAI). In general, the content of TChl and $\mathrm{Cx}+\mathrm{c}$ was lower in Foph-inoculated plants compared with noninoculated plants under waterlogging conditions. BR, SA, or EB sprays generated an increase in the photosynthetic pigment concentration (TChl and $\mathrm{Cx}+\mathrm{c}$ ) in cape gooseberry plants subjected to a waterlogging period for both inoculation conditions (with and without Foph) (Fig. 5A and B).

MDA production and leaf proline content. Significant differences were observed between Foph inoculation and synthetic elicitor sprays on MDA production $(P=0.0000)$ and leaf proline content $(P=0.0008)$ of cape gooseberry plants under waterlogging conditions at 51 DAI. Regarding these biochemical variables, opposite effects were observed in waterlogged cape gooseberry plants under both inoculation conditions (with and without Foph). A reduction of lipid peroxidation (MDA) was obtained with the application of elicitors (BR, SA, or BE), whereas a higher proline production was recorded under the foliar sprays of these inducers (Fig. 5C and D).

Biplot analysis of physiological and biochemical responses to Foph management with synthetic elicitors under waterlogging conditions. The principal component analysis showed that the evaluated variables explained $96.6 \%$ of the physiological response of cape gooseberry plants infected with Foph, subjected to waterlogging, and treated with synthetic elicitors at 51 DAI. Figure 6A shows the evaluated variables represented by vectors and the plants of the different treatments identified with points. The vectors generated for the variables $g_{\mathrm{S}}$, $\Psi_{\mathrm{wf}}$, TDW, LA, stem diameter, $\mathrm{F}_{\mathrm{v}} / \mathrm{F}_{\mathrm{m}}$, ETR, $\mathrm{qP}, \mathrm{TChl}, \mathrm{Cx}+\mathrm{c}$, and proline present angles close to the origin, showing that there is a high correlation between these variables and the plant physiological behavior. It was observed that Foph-inoculated plants without the application of elicitors under waterlogging conditions (plants + Foph $+W$ ) form a single group (I). It can be inferred that this group presented the greatest effects due to the evaluated interaction of biotic and abiotic stresses. In contrast, noninoculated plants, subjected to a short waterlogging period (6 d) and with and without BR, SA, or BE sprays (group III), were located in the sector opposite to group I, observing a positive effect of the treatments on plant physiology. On the other hand, plants with Foph under waterlogging and sprayed with the synthetic elicitors (BR, SA, or BE) showed an intermediate behavior (group II), evidencing a positive effect of the treatments with elicitors on the mitigation of the interaction between the two stresses (Foph + waterlogging). This analysis is corroborated by the cluster analysis, with the dendrogram reflecting a lower Euclidean distance between waterlogged plants with and without Foph inoculation and synthetic elicitor sprays (BR, SA, or BE). This group of plants is notably farther from the plants inoculated with the pathogen and without synthetic elicitor sprays under waterlogging conditions (Fig. 6B).

Comparative analysis of vascular wilt and waterlogging mitigation by synthetic elicitor sprays. Table 2 shows the effect of foliar BR, $\mathrm{SA}$, or BE sprays on Foph-inoculated cape gooseberry plants under waterlogging conditions (plants $+\mathrm{W}+$ Foph), Foph-inoculated plants without the waterlogging condition (plants + Foph), plants without Foph inoculation under waterlogging conditions (plants + $\mathrm{W})$, and noninoculated plants without waterlogging and without elicitor sprays (plants without stress) at 51 DAI. These results demonstrated that three foliar BR, $\mathrm{SA}$, or BE sprays helped plants to cope with the combined condition of vascular wilt and waterlogging, because a positive stimulus of these elicitors was observed on physiological and biochemical variables, such as $g_{\mathrm{S}}, \Psi_{\mathrm{wf}}$, TDW, LA, TChl, $\mathrm{Cx}+\mathrm{c}, \mathrm{F}_{\mathrm{v}} / \mathrm{F}_{\mathrm{m}}$, ETR, MDA, and proline. In addition, the RTI based on the TDW corroborated that the foliar applications with $\mathrm{BR}, \mathrm{SA}$, or BE help to tolerate the double-stress condition in cape gooseberry plants, observing an RTI between $61.3 \%$ and $71.4 \%$ compared with the RTI of $51.3 \%$ observed in plants subjected to the two stress conditions (Foph and waterlogging) (Fig. 7).

\section{Discussion}

The results obtained in this research confirmed previous observations in which $\mathrm{BR}, \mathrm{SA}$, or BE reduces Foph severity under oxygen deficit in the soil. BR, SA, or BE caused a decrease in the development of vascular wilt caused by $F$. oxysporum, which also has been documented in cucumber, tomato, and pepper, respectively (Ding et al., 2009b; Poussio et al., 2018; Yousif, 2018). BR decreases vascular wilt severity because it can participate in several physiological processes that activate the defense system (Anwar et al., 2018; Peres et al., 2019). This synthetic elicitor can also be involved in the expression of pathogenesisrelated proteins, which lead to an increase in the resistance to pathogens (Ding et al., 2009b; Filek et al., 2018; Saini et al., 2015). In addition, SA can contribute to the regulation of defense against biotrophic and hemibiotrophic pathogens; it plays a key role in the systemic acquired resistance of plants, the modulation of the hypersensitivity response associated with programmed cell death, the increase in the levels of reactive oxygen species, and the activation of lipid peroxidation (Bernsdorff et al., 2016; Dempsey and Klessig, 2017; Qi et al., 2018). Finally, 


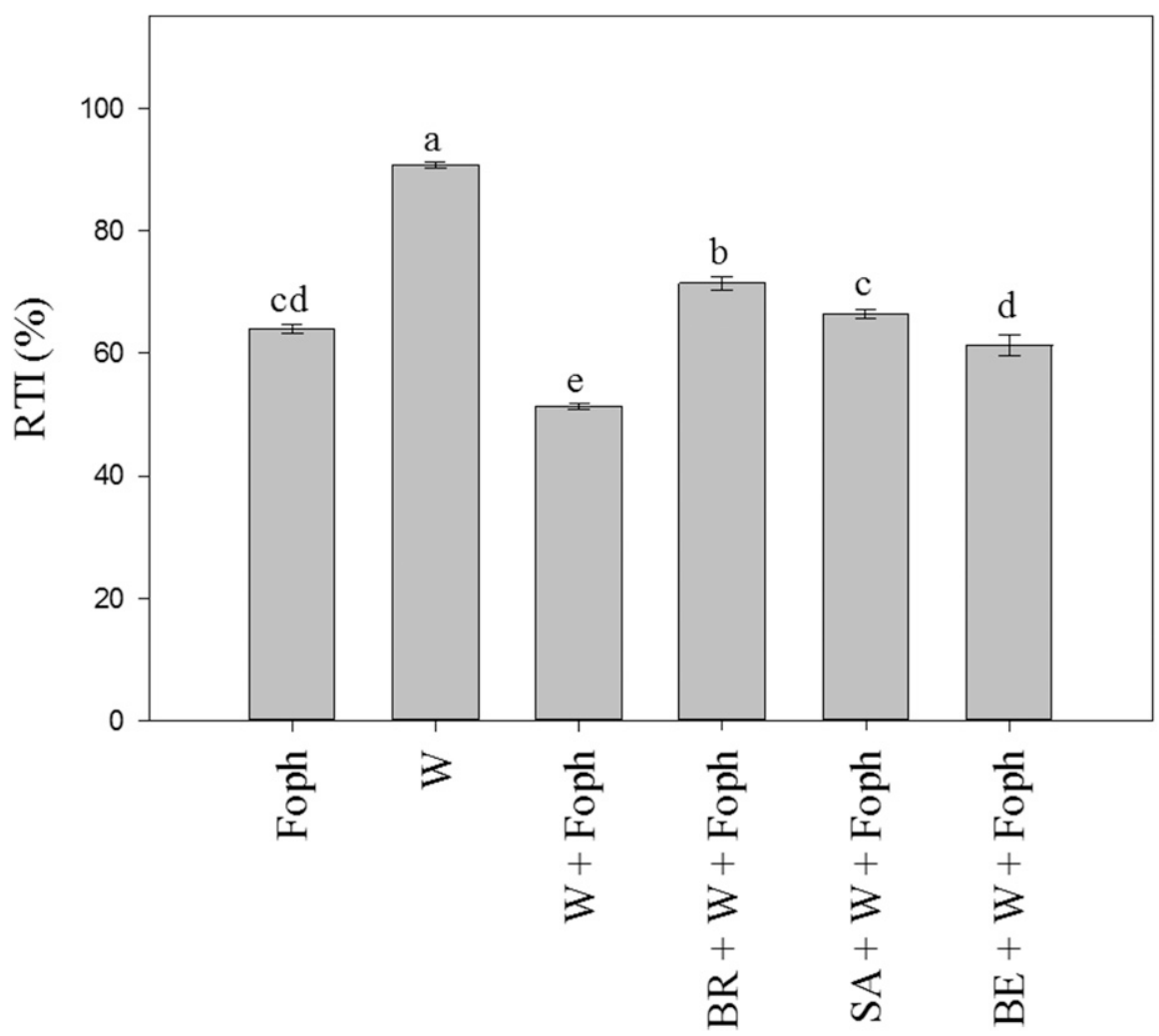

Fig. 7. Effect of synthetic elicitor [brassinosteroids (BR), salicylic acid (SA), or botanical extracts (BE) of Echinacea purpurea, Potentilla erecta, and Aloe vera] sprays on the relative tolerance index (RTI) of cape gooseberry plants with and without Fusarium oxysporum f. sp. physali (Foph) subjected to a short period of waterlogging (W) (6 d) at $51 \mathrm{~d}$ after inoculation (DAI). Data represent the average of five plants \pm SE per treatment $(n=5)$. Bars followed by different letters indicate statistically significant differences according to the Tukey test $(P \leq 0.05)$.

different BEs are constituted by aromatic hydrocarbons, such as phenylpropanoids, which are involved in various diseaseresistance responses through secondary metabolite synthesis ( $\mathrm{Li}$ et al., 2017). In this sense, commercial products based on different BEs also are rich in polysaccharides and amino acids that can induce plant defense (Jayaraman et al., 2011; Shifa et al., 2018).

Foliar synthetic elicitors sprays favored physiological and biochemical parameters, especially in cape gooseberry plants affected by hypoxia conditions in the soil. In the present study, three foliar $\mathrm{BR}, \mathrm{SA}$, or $\mathrm{BE}$ sprays had a positive effect mainly on the variables $g_{\mathrm{S}}, \Psi_{\mathrm{wf}}$, growth, photosynthetic pigments, MDA, and proline. It has been reported that exogenous BR sprays at low concentrations $\left(1 \mathrm{mg} \cdot \mathrm{L}^{-1}\right)$ can help the osmotic adjustment and induce stomatal opening. These responses improve leaf gas exchange properties, plant water status, photosynthetic pigment contents, and photochemical activity of PSII, which favor plant growth under waterlogging stress conditions (Kang et al., 2017; Li et al., 2015a; Lima and Lobato, 2017; Xia et al., 2014). Likewise, the positive effects of SA on the physiological behavior of plants under waterlogging stress conditions may be because this hormone plays an important role in the leaf's stomatal opening and closing, the synthesis of photosynthetic pigments, the stability of membrane the increase of chlorophyll fluorescence parameters $\left(\mathrm{F}_{\mathrm{v}} / \mathrm{F}_{\mathrm{m}}\right.$ and ETR $)$ and the activity of antioxidant enzymes. Under stress conditions, BR can regulate physiological processes, such as the reduction of electrolyte leakage and MDA content. Furthermore, this synthetic elicitor also can increase proline accumulation, soluble sugars, total phenolic and glutathione contents, and antioxidant machinery activation (Anwar et al., 2018; Nawaz et al., 2017; Vardhini and Anjum, 2015). The preceding explains the positive effect of BR, which is superior at conferring tolerance to the two stress conditions (Foph and waterlogging) compared with the other elicitors evaluated in cape gooseberry plants.

SA is a plant hormone that is involved in the activation of plant defense responses against a wide range of abiotic and biotic stresses (Cekic, 2017; Fragnière et al., 2011; Hernández-Ruiz and Arnao, 2018). Studies by Mann et al. (2011) showed that foliar SA applications mitigated the negative effect of the combination of thermal stress and Huanglongbing presence in citrus fruits (Citrus sinensis L.). The evaluated variables ( $g_{\mathrm{S}}$, $\Psi_{\mathrm{wf}}$, growth, fluorescence parameters, MDA, and proline content) were favored after SA sprays in cape gooseberry plants under the combined stress condition (Foph and waterlogging) in the present experiment This may be because SA is related to the activation of cell division in the meristems and the improvement of the photosynthetic rate, carboxylase activity of the Rubisco enzyme, and membrane stability. In addition, this synthetic elicitor also increases phenols, chlorophyll, carbohydrates, and proline contents, and promotes the activity of antioxidant enzymes (Asgharei, 2015; Hayat et al., 2010; Khoshbakht and Su et al., 2018).

The use of $\mathrm{BE}$ can be considered a promising strategy to help the plant under conditions of abiotic and biotic stress (Ben Salah et al., 2018; Santaniello et al., 2017; Shukla et al., 2017). Maymoune et al. (2015) observed that the application of BE of green algae (Ulva sp.) decreased the necrosis diameter, inhibited spore germination, and increased protection efficacy in tomato plants (Solanum lycopersicum L.) infected with Botrytis cinerea under water stress conditions. Although BR and SA sprays showed better results than those obtained with $\mathrm{BE}$ from plants of $E$. purpurea, $P$. erecta, and $A$. vera, these extracts also favored the physiological response of Foph-inoculated cape gooseberry plants under hypoxia conditions in the soil. This positive effect of BE can be because these compounds stimulate plant growth and development, improve water and nutrient uptake efficiency, regulate stomatal dynamics, and increase the ascorbate content and the antioxidant enzyme activity (Carvalho et al., 2018; Guinan et al., 2012; Howladar, 2014; Shukla et al., 2017).

\section{Conclusion}

This study showed that sprays of synthetic elicitors, such as BR, SA, or BE, 
reduced vascular wilt severity by improving the physiological and biochemical response of Foph-infected cape gooseberry plants under hypoxia conditions in the soil. Likewise, it was observed that the use of these elicitors has positive effects on plant physiology, favoring $g_{\mathrm{S}}, \Psi_{\mathrm{wf}}$, growth (expressed as dry matter accumulation and LA), photochemical efficiency of PSII, ETR, qP, TChl, and proline content. Synthetic elicitor sprays also showed a significant reduction of NPQ and lipid peroxidation of membranes under a combination of stress conditions (Foph + waterlogging); however, additional research is needed on topics such as gene expression as a product of these synthetic elicitor sprays. In addition, field trials are suggested to evaluate the effect of $\mathrm{BR}, \mathrm{SA}$, or $\mathrm{BE}$ on crop yield and fruit quality parameters under the interaction of these two stresses (Foph and waterlogging). The obtained results suggest that BR, SA, or EB sprays in cape gooseberry plants could be considered as an alternative for the integrated management of vascular wilt in cape gooseberry-producing areas where waterlogging episodes could be expected.

\section{Literature Cited}

Abdallah, R.A.B., H. Jabnoun-Khiareddine, A. Nefzi, S. Mokni-Tlili, and M. Daami-Remadi. 2016. Biocontrol of fusarium wilt and growth promotion of tomato plants using endophytic bacteria isolated from Solanum elaeagnifolium stems. J. Phytopathol. 164(10):811-824.

Agronet. 2019. Área, Producción y Rendimiento Nacional de uchuva en Colombia. Red de información y comunicación del sector agropecuario. 20 May 2019.<www.agronet.gov.co/ estadistica/Paginas/home.aspx?cod $=1 \#>$.

Aguilar, E.A., D.W. Turner, and K. Sivasithamparam. 2000. Fusarium oxysporum f. sp. cubense inoculation and hypoxia alter peroxidase and phenylalanine ammonia lyase activities in nodal roots of banana cultivars (Musa sp.) differing in their susceptibility to Fusarium wilt. Aust. J. Bot. 48(5):589-596.

Aldana, F., P.N. García, and G. Fischer. 2014. Effect of waterlogging stress on the growth, development and symptomatology of cape gooseberry (Physalis peruviana L.) plants. Rev. Acad. Colomb. Cienc. Exactas Fis. Nat. 38(14):393-400.

Álvarez-Flórez, F., C. López-Cristoffanini, O. Jáuregui, L.M. Melgarejo, and M. LópezCarbonell. 2017. Changes in ABA, IAA and JA levels during calyx, fruit and leaves development in cape gooseberry plants (Physalis peruviana L.). Plant Physiol. Biochem. 115:174-182.

Alves, D.P., R.S. Tomaz, B.S. Laurindo, R.D.F. Laurindo, C.D. Cruz, C. Nick, and D.J.H.D. Silva. 2017. Artificial neural network for prediction of the area under the disease progress curve of tomato late blight. Sci. Agr. 74(1):51-59.

Anwar, A., Y. Liu, R. Dong, L. Bai, X. Yu, and Y. Li. 2018. The physiological and molecular mechanism of brassinosteroid in response to stress: A review. Biol. Res. 51:46.

Bai, T., C. Li, F. Ma, H. Shu, and M. Han. 2009. Exogenous salicylic acid alleviates growth inhibition and oxidative stress induced by hypoxia stress in Malus robusta Rehd. J. Plant Growth Regul. 28(4):358-366.
Bates, L.S., R.P. Waldren, and I.D. Teare. 1973. Rapid determination of free proline for waterstress studies. Plant Soil 39(1):205-207.

Bektas, Y. and T. Eulgem. 2015. Synthetic plant defense elicitors. Front. Plant Sci. 5:804.

Ben Salah, I., S. Aghrouss, A. Douira, S. Aissam, Z. El Alaoui-Talibi, A. Filali-Maltouf, and C. El Modafar. 2018. Seaweed polysaccharides as bio-elicitors of natural defenses in olive trees against verticillium wilt of olive. J. Plant Interact. 13(1):248-255.

Bernal-Vicente, A., C. Petri, J.A. Hernandez, and P. Diaz-Vivancos. 2017. The effect of abiotic and biotic stress on the salicylic acid biosynthetic pathway from mandelonitrile in peach. bioRxiv 204636.

Bernsdorff, F., A.C. Döring, K. Gruner, S. Schuck, A. Bräutigam, and J. Zeier. 2016. Pipecolic acid orchestrates plant systemic acquired resistance and defense priming via salicylic aciddependent and - independent pathways. Plant Cell 28:102-129.

Bibi, N., K. Fan, M. Dawood, G. Nawaz, S. Yuan, and W. Xuede. 2014. Exogenous application of epibrassinolide attenuated Verticillium wilt in upland cotton by modulating the carbohydrates metabolism, plasma membrane ATPases and intracellular osmolytes. Plant Growth Regulat. 73(2):155-164.

Bogatek, R. and A. Gniazdowska. 2007. ROS and phytohormons in plant-plant allelopathic interaction. Plant Signal. Behav. 2(4):317-318.

Campbell, C.L. and L.V. Madden. 1990. Introduction to plant disease epidemiology. First ed. Wiley-Interscience, New York.

Carvalho, M.E.A., P.R. de Camargo, S.A. Gaziola, and R.A. Azevedo. 2018. Is seaweed extract an elicitor compound? Changing proline content in drought-stressed bean plants. Comun. Sci. 9(2):292-297.

Cekic, F.O. 2017. Effects of salicylic acid on gaba metabolism in pepper plants under stress conditions. Hacet. J. Biol. Chem. 45(3):359-364.

Chávez-Arias, C.C., S. Gómez-Caro, and H. Restrepo-Díaz. 2019. Physiological, biochemical and chlorophyll fluorescence parameters of Physalis Peruviana L. seedlings exposed to different short-term waterlogging periods and fusarium wilt infection. Agronomy 9(5):213.

Chiang, K.S., H.I. Liu, and C.H. Bock. 2017. A discussion on disease severity index values. Part I: Warning on inherent errors and suggestions to maximise accuracy. Ann. Appl. Biol. 171(2):139-154.

Chojak-Koźniewska, J., E. Kuźniak, and J. Zimny. 2018. The effects of combined abiotic and pathogen stress in plants: Insights from salinity and Pseudomonas syringae pv lachrymans interaction in cucumber. Front. Plant Sci. 9:1691.

Csiszár, J., S. Brunner, E. Horváth, K. Bela, P. Ködmön, R. Riyazuddin, Á. Gallé, Á. Hurton, C. Papdi, L. Szabados, and I. Tari. 2018. Exogenously applied salicylic acid maintains redox homeostasis in salt-stressed Arabidopsis grl mutants expressing cytosolic roGFP1. Plant Growth Regulat. 86(2):181-194.

Dar, M.I., M.I. Naikoo, F. Rehman, F. Naushin, and F.A. Khan. 2016. Proline accumulation in plants: Roles in stress tolerance and plant development, p. 155-166. In: N. Iqbal, R. Nazar, and N.A. Khan (eds.). Osmolytes and plants acclimation to changing environment: Emerging omics technologies. Springer, New Delhi, India.

Dempsey, D.A. and D.F. Klessig. 2017. How does the multifaceted plant hormone salicylic acid combat disease in plants and are similar mechanisms utilized in humans? BMC Biol. 15:23.

Ding, J., K. Shi, Y.H. Zhou, and J.Q. Yu. 2009a. Effects of root and foliar applications of 24-epibrassinolide on Fusarium wilt and antioxidant metabolism in cucumber roots. HortScience 44:1340-1345.

Ding, J., K. Shi, Y.H. Zhou, and J.Q. Yu. 2009b. Microbial community responses associated with the development of Fusarium oxysporum f. sp. cucumerinum after 24-epibrassinolide applications to shoots and roots in cucumber. Eur. J. Plant Pathol. 124(1):141-150.

Duncan, J.M. and D.M. Kennedy. 1989. The effect of waterlogging on Phytophthora root rot of red raspberry. Plant Pathol. 38(2):161-168.

Dutta Gupta, S., R.M. Auge, P.D. Denchev, and B.V. Conger. 1995. Growth, proline accumulation and water relations in $\mathrm{NaCl}$-selected and non-selected callus lines of Dactylis glomerata. Environ. Expt. Bot. 35(1):83-92.

Elansary, H.O., K. Yessoufou, A.M. Abdel-Hamid, M.A. El-Esawi, H.M. Ali, and M.S. Elshikh. 2017. Seaweed extracts enhance Salam turfgrass performance during prolonged irrigation intervals and saline shock. Front. Plant Sci. 8:830.

Fariduddin, Q., M. Yusuf, I. Ahmad, and A. Ahmad. 2014. Brassinosteroids and their role in response of plants to abiotic stresses. Biol. Plant. 58(1):9-17.

Farooq, M., M. Rizwan, A. Nawaz, A. Rehman, and R. Ahmad. 2017. Application of natural plant extracts improves the tolerance against combined terminal heat and drought stresses in bread wheat. J. Agron. Crop Sci. 203(6):528538.

Filek, M., A. Sieprawska, J. Oklestkova, E. Rudolphi-Skórska, J. Biesaga-Kościelniak, Z. Miszalski, and A. Janeczko. 2018. 24-Epibrassinolide as a modifier of antioxidant activities and membrane properties of wheat cells in zearalenone stress conditions. J. Plant Growth Regul. 37(4):1085-1098.

Fragnière, C., M. Serrano, E. Abou-Mansour, J.P. Métraux, and F. L'haridon. 2011. Salicylic acid and its location in response to biotic and abiotic stress. FEBS Lett. 585(12):1847-1852.

Groves, E., K. Howard, G. Hardy, and T. Burgess. 2015. Role of salicylic acid in phosphiteinduced protection against Oomycetes; a Phytophthora cinnamomi-Lupinus augustifolius model system. Eur. J. Plant Pathol. 141(3):559-569.

Guinan, K.J., N. Sujeeth, R.B. Copeland, P.W. Jones, N.M. O'brien, H.S.S. Sharma, P.F.J. Prouteau, and J.T. O'Sullivan. 2012. Discrete roles for extracts of Ascophyllum nodosum in enhancing plant growth and tolerance to abiotic and biotic stresses. Acta Hort. 1009:127-135.

Hainaut, P., T. Remacle, C. Decamps, R. Lambert, and W. Sadok. 2016. Higher forage yields under temperate drought explained by lower transpiration rates under increasing evaporative demand. Eur. J. Agron. 72:91-98.

Hara, M., J. Furukawa, A. Sato, T. Mizoguchi, and K. Miura. 2012. Abiotic stress and role of salicylic acid in plants, p. 235-251. In: P. Ahmad and M.N.V. Prasad (eds.). Abiotic stress responses in plants. Springer, New York.

Hayat, Q., S. Hayat, M. Irfan, and A. Ahmad. 2010. Effect of exogenous salicylic acid under changing environment: A review. Environ. Expt. Bot. 68(1):14-25.

He, L., L. Yu, B. Li, N. Du, and S. Guo. 2018. The effect of exogenous calcium on cucumber fruit quality, photosynthesis, chlorophyll fluorescence, and fast chlorophyll fluorescence during 
the fruiting period under hypoxic stress. BMC Plant Biol. 18:180.

Hernández-Ruiz, J. and M. Arnao. 2018. Relationship of melatonin and salicylic acid in biotic/ abiotic plant stress responses. Agronomy 8(4):33.

Herzog, M., G.G. Striker, T.D. Colmer, and O. Pedersen. 2016. Mechanisms of waterlogging tolerance in wheat-a review of root and shoot physiology. Plant Cell Environ. 39(5):10681086.

Hodges, D.M., J.M. DeLong, C.F. Forney, and R.K. Prange. 1999. Improving the thiobarbituric acid-reactive-substances assay for estimating lipid peroxidation in plant tissues containing anthocyanin and other interfering compounds. Planta 207(4):604-611.

Howladar, S.M. 2014. A novel Moringa oleifera leaf extract can mitigate the stress effects of salinity and cadmium in bean (Phaseolus vulgaris L.) plants. Ecotoxicol. Environ. Saf. 100:69-75.

Irulappan, V. and M. Senthil-Kumar. 2018. Morphophysiological traits and molecular intricacies associated with tolerance to combined drought and pathogen stress in plants, p. 59-74. In: S.S. Gosal and S.H. Wani (eds.). Biotechnologies of crop improvement. Springer, Cham, Switzerland.

Jabran, K. and M. Farooq. 2013. Implications of potential allelopathic crops in agricultural systems, p. 349-385. In: Z.A. Cheema, M. Farooq, and A. Wahid (eds.). Allelopathy current trends and future applications. Springer, Berlin, Germany.

Jayaraman, J., J. Norrie, and Z.K. Punja. 2011. Commercial extract from the brown seaweed Ascophyllum nodosum reduces fungal diseases in greenhouse cucumber. J. Appl. Phycol. 23(3):353-361.

Joseph, A., E.A. Ese, B.O. Ademiluyi, and P.A. Aluko. 2017. Efficacy of selected plant extracts in the management of tomato early blight disease caused by Alternaria solani. Asian J. Plant Pathol. 11(1):48-52.

Kang, Y.H., A. Breda, and C.S. Hardtke. 2017. Brassinosteroid signaling directs formative cell divisions and protophloem differentiation in Arabidopsis root meristems. Development 144:272-280.

Khan, M.I.R., M. Fatma, T.S. Per, N.A. Anjum, and N.A. Khan. 2015. Salicylic acid-induced abiotic stress tolerance and underlying mechanisms in plants. Front. Plant Sci. 6:462.

Khoshbakht, D. and M.R. Asgharei. 2015. Influence of foliar-applied salicylic acid on growth, gas-exchange characteristics, and chlorophyll fluorescence in citrus under saline conditions. Photosynthetica 53(3):410-418.

Król, P., R. Igielski, S. Pollmann, and E. Kępczyńska. 2015. Priming of seeds with methyl jasmonate induced resistance to hemi-biotroph Fusarium oxysporum f. sp. lycopersici in tomato via 12-oxo-phytodienoic acid, salicylic acid, and flavonol accumulation. J. Plant Physiol. 179:122-132.

Leslie, J.F. and B.A. Summerell. 2006. The Fusarium laboratory manual. 1st ed. Blackwell Publishing, Ames, IA.

Li, J., P. Yang, Y. Gan, J. Yu, and J. Xie. 2015a. Brassinosteroid alleviates chilling-induced oxidative stress in pepper by enhancing antioxidation systems and maintenance of photosystem II. Acta Physiol. Plant. 37:222.

Li, Y.P., M.P. You, T.D. Colmer, and M.J. Barbetti. 2015b. Effect of timing and duration of soil saturation on soilborne Pythium diseases of common bean (Phaseolus vulgaris). Plant Dis. 99(1):112-118.
Li, G., S. Zhu, W. Wu, C. Zhang, Y. Peng, Q. Wang, and J. Shi. 2017. Exogenous nitric oxide induces disease resistance against Monilinia fructicola through activating the phenylpropanoid pathway in peach fruit. J. Sci. Food Agr. 97(9):3030-3038.

Lima, J.V. and A.K.S. Lobato. 2017. Brassinosteroids improve photosystem II efficiency, gas exchange, antioxidant enzymes and growth of cowpea plants exposed to water deficit. Physiol. Mol. Biol. Plants 23(1):59-72.

Liu, Z., R. Cheng, W. Xiao, Q. Guo, and N. Wang. 2014. Effect of off-season flooding on growth, photosynthesis, carbohydrate partitioning, and nutrient uptake in Distylium chinense. PLoS One 9(9):e107636.

Llorens, E., P. García-Agustín, and L. Lapeña. 2017. Advances in induced resistance by natural compounds: Towards new options for woody crop protection. Sci. Agr. 74(1):90-100.

Mandal, S., N. Mallick, and A. Mitra. 2009. Salicylic acid-induced resistance to Fusarium oxysporum f. sp. lycopersici in tomato. Plant Physiol. Biochem. 47(7):642-649.

Mann, K.K., A.W. Schumann, and T.M. Spann. 2011. Response of citrus to exogenously applied salicylate compounds during abiotic and biotic stress. Proc. Annu. Meet. Fla. State Hort. Soc. 124:101-110.

Mansori, M., H. Chernane, S. Latique, A. Benaliat, D. Hsissou, and M. El Kaoua. 2015. Seaweed extract effect on water deficit and antioxidative mechanisms in bean plants (Phaseolus vulgaris L.). J. Appl. Phycol. 27(4):1689-1698.

Maymoune, A., P. Adeline, T. Marie, G. Sophie, C. Sophie, L. Catherine, N. Claire, and H. Sonia. 2015. Impact of abiotic stresses on the protection efficacy of defence elicitors and on metabolic regulation in tomato leaves infected by Botrytis cinerea. Eur. J. Plant Pathol. 142(2):223-237.

McGovern, R.J. 2015. Management of tomato diseases caused by Fusarium oxysporum. Crop Prot. 73:78-92.

Moreno-Velandia, C.A. 2017. Interactions between Bacillus amyloliquefaciens Bs006, Fusarium oxysporun Map5 and Cape gooseberry (Physalis peruviana). Natl. Univ. of Colombia, Bogotá, PhD Diss.

Moreno-Velandia, C.A., L.F. Izquierdo-García, M. Ongena, J.W. Kloepper, and A.M. Cotes. 2019. Soil sterilization, pathogen and antagonist concentration affect biological control of Fusarium wilt of cape gooseberry by Bacillus velezensis Bs006. Plant Soil 435(1-2):39-55.

Moslemi, A., P.K. Ades, T. Groom, M.E. Nicolas, and P.W. Taylor. 2018. Influence of waterlogging on growth of pyrethrum plants infected by the crown and root rot pathogens, Fusarium oxysporum, Fusarium avenaceum and Paraphoma vinacea. Austral. Plant Pathol. 47(2): 205-213.

Mostafa, A.A., A.A. Al-Askar, K.S. Almaary, T.M. Dawoud, E.N. Sholkamy, and M.M. Bakri. 2018. Antimicrobial activity of some plant extracts against bacterial strains causing food poisoning diseases. Saudi J. Biol. Sci. 25(2):361-366.

Naik, P.M. and J.M. Al-Khayri. 2016. Abiotic and biotic elicitors - role in secondary metabolites production through in vitro culture of medicinal plants, p. 247-277. In: A. Shanker and C. Shanker (eds.). Abiotic and biotic stress in plants - recent advances and future perspectives. IntechOpen, Rijeka, Croatia.

Nawaz, F., M. Naeem, B. Zulfiqar, A. Akram, M.Y. Ashraf, M. Raheel, R.N. Shabbir, R.A. Hussain, I. Anwar, and M. Aurangzaib. 2017. Under- standing brassinosteroid-regulated mechanisms to improve stress tolerance in plants: A critical review. Environ. Sci. Pollut. Res. Int. 24(19):15959-15975.

Olivares-Tenorio, M.L., M. Dekker, M.A. van Boekel, and R. Verkerk. 2017. Evaluating the effect of storage conditions on the shelf life of cape gooseberry (Physalis peruviana L.). Lebensm. Wiss. Technol. 80:523-530.

Osorio-Guarín, J.A., F.E. Enciso-Rodríguez, C. González, N. Fernández-Pozo, L.A. Mueller, and L.S. Barrero. 2016. Association analysis for disease resistance to Fusarium oxysporum in cape gooseberry (Physalis peruviana L). BMC Genomics 17:248.

Otie, V., A. Ping, I. Udo, and E. Eneji. 2019 Brassinolide effects on maize (Zea mays L.) growth and yield under waterlogged conditions. J. Plant Nutr. 42(8):954-969.

Pandey, P., V. Irulappan, M.V. Bagavathiannan, and M. Senthil-Kumar. 2017. Impact of combined abiotic and biotic stresses on plant growth and avenues for crop improvement by exploiting physio-morphological traits. Front. Plant Sci. 8:537.

Park, D. 1961. Isolation of Fusarium oxysporum from soils. Trans. Br. Mycol. Soc. 44(1):119122.

Peres, A.L.G., J.S. Soares, R.G. Tavares, G. Righetto, M.A. Zullo, N.B. Mandava, and M. Menossi. 2019. Brassinosteroids, the sixth class of Phytohormones: A molecular view from the discovery to hormonal interactions in plant development and stress adaptation. Int. J. Mol. Sci. 20(2):331.

Poussio, G.B., M.A. Abro, J.U. Hajano, M.I. Khaskheli, K.I. Rajput, and S.R. Memon. 2018. Potential of plant extracts and fungicides for managing Fusarium oxysporum f. sp lycopersici. Pak. J. Phytopathol. 30(1):75-81.

Procolombia. 2019. Uchuva (Goldenberry). Exportaciones, turismo, inversion marca país. $18 \mathrm{Apr}$. 2019. <www.procolombia.co/docs/int-procolombia/es/exportaciones/ficha_uchuva_final. pdf $>$.

Qi, G., J. Chen, M. Chang, H. Chen, K. Hall, J. Korin, F. Liu, D. Wang, and Z.Q. Fu. 2018. Pandemonium breaks out: Disruption of salicylic acid-mediated defense by plant pathogens. Mol. Plant 11(12):1427-1439.

Ramírez-Godoy, A., M.P. Vera-Hoyos, N. JiménezBeltrán, and H. Restrepo-Diaz. 2018. Application of foliar synthetic elicitors for the management of Diaphorina citri (Hemiptera: Liviidae) populations in Tahiti lime (Citrus latifolia Tanaka). HortScience 53:1012-1020.

Rao, X. and R.A. Dixon. 2017. Brassinosteroid mediated cell wall remodeling in grasses under abiotic stress. Front. Plant Sci. 8:806.

Rao, R. and Y. Li. 2003. Management of flooding effects on growth of vegetable and selected field crops. HortTechnology 13:610-616.

Rongai, D., P. Pulcini, B. Pesce, and F. Milano. 2017. Antifungal activity of pomegranate peel extract against fusarium wilt of tomato. Eur. J. Plant Pathol. 147(1):229-238.

Roussos, P.A., N.K. Denaxa, T. Damvakaris, V. Stournaras, and I. Argyrokastritis. 2010. Effect of alleviating products with different mode of action on physiology and yield of olive under drought. Scientia Hort. 125(4):700-711.

Saini, S., I. Sharma, and P.K. Pati. 2015. Versatile roles of brassinosteroid in plants in the context of its homoeostasis, signaling and crosstalks. Front. Plant Sci. 6:950.

Santaniello, A., A. Scartazza, F. Gresta, E. Loreti, A. Biasone, D. Di Tommaso, A. Piaggesi, and P. Perata. 2017. Ascophyllum nodosum seaweed 
extract alleviates drought stress in Arabidopsis by affecting photosynthetic performance and related gene expression. Front. Plant Sci. 8:1362.

Shao, G.C., J.J. Lan, S.E. Yu, N. Liu, R.Q. Guo, and D.L. She. 2013. Photosynthesis and growth of winter wheat in response to waterlogging at different growth stages. Photosynthetica 51(3): 429-437.

Shifa, H., C. Gopalakrishnan, and R. Velazhahan. 2018. Management of late leaf spot (Phaeoisariopsis personata) and root rot (Macrophomina phaseolina) diseases of groundnut (Arachis hypogaea L.) with plant growthpromoting rhizobacteria, systemic acquired resistance inducers and plant extracts. Phytoparasitica 46(1):19-30.

Shivas, R.G., P.M. Wood, M.W. Darcey, and K.G. Peg. 1995. First record of Fusarium oxysporum f. sp. cubense on Cavendish bananas in Western Australia. Austral. Plant Pathol. 24(1):38-43.

Shukla, P.S., K. Shotton, E. Norman, W. Neily, A.T. Critchley, and B. Prithiviraj. 2017. Seaweed extract improve drought tolerance of soybean by regulating stress-response genes. AoB Plants 10(1):plx051.

Simbaqueba, J., A.M. Catanzariti, C. González, and D.A. Jones. 2018. Evidence for horizontal gene transfer and separation of effector recognition from effector function revealed by analysis of effector genes shared between cape gooseberry-and tomato-infecting formae speciales of Fusarium oxysporum. Mol. Plant Pathol. 19(10):2302-2318.

Sims, D.A. and J.A. Gamon. 2002. Relationships between leaf pigment content and spectral reflectance across a wide range of species, leaf structures and developmental stages. Remote Sens. Environ. 81(2-3):337-354.
Singh, S.K., A.K. Singh, and P. Dwivedi. 2017. Modulating effect of salicylic acid in tomato plants in response to waterlogging stress. Intl. J. Agr. Environ. Biotechnol. 10(1):1-8.

Su, H., S. Song, X. Yan, L. Fang, B. Zeng, and Y. Zhu. 2018. Endogenous salicylic acid shows different correlation with baicalin and baicalein in the medicinal plant Scutellaria baicalensis Georgi subjected to stress and exogenous salicylic acid. PLoS One 13(2):e0192114.

Suzuki, N., R.M. Rivero, V. Shulaev, E. Blumwald, and R. Mittler. 2014. Abiotic and biotic stress combinations. New Phytol. 203(1):32-43.

Thakur, M. and B.S. Sohal. 2013. Role of elicitors in inducing resistance in plants against pathogen infection: A review. ISRN Biochem. 2013:762412.

Van Oosten, M.J., O. Pepe, S. De Pascale, S. Silletti, and A. Maggio. 2017. The role of biostimulants and bioeffectors as alleviators of abiotic stress in crop plants. Chem. Biol. Technol. Agr. 4:5.

Vardhini, B.V. and N.A. Anjum. 2015. Brassinosteroids make plant life easier under abiotic stresses mainly by modulating major components of antioxidant defense system. Front. Environ. Sci. 2:67.

Villarreal-Navarretex, A., G. Fischer, L.M. Melgarejo, G. Correa, and L. Hoyos-Carvajal. 2017. Growth response of the cape gooseberry (Physalis peruviana L.) to waterlogging stress and Fusarium oxysporum infection. Acta Hort. 1178: 161-168.

Wellburn, A.R. 1994. The spectral determination of chlorophylls $a$ and $b$, as well as total carotenoids, using various solvents with spectrophotometers of different resolution. J. Plant Physiol. 144(3):307-313.

Wilcox, W.F. 1993. Incidence and severity of crown and root rots on four apple rootstocks following exposure to Phytophthora species and waterlogging. J. Amer. Soc. Hort. Sci. 118(1):63-67.

Wu, X., Y. Tang, C. Li, C. Wu, and G. Huang. 2015. Chlorophyll fluorescence and yield responses of winter wheat to waterlogging at different growth stages. Plant Prod. Sci. 18(3):284-294

Xia, X.J., Y.J. Wang, Y.H. Zhou, Y. Tao, W.H. Mao, K. Shi, T. Asami, Z. Chen, and J.Q. Yu. 2009. Reactive oxygen species are involved in brassinosteroid-induced stress tolerance in cucumber. Plant Physiol. 150:801-814.

Xia, X.J., C.J. Gao, L.X. Song, Y.H. Zhou, K.A.I. Shi, and J.Q. Yu. 2014. Role of $\mathrm{H}_{2} \mathrm{O}_{2}$ dynamics in brassinosteroid-induced stomatal closure and opening in Solanum lycopersicum. Plant Cell Environ. 37(9):2036-2050.

Xue, L.J., W. Guo, Y. Yuan, E.O. Anino, B. Nyamdari, M.C. Wilson, C.J. Frost, H.Y. Chen, B.A. Babst, S.A. Harding, and C.J. Tsai. 2013. Constitutively elevated salicylic acid levels alter photosynthesis and oxidative state but not growth in transgenic Populus. Plant Cell 25(7):2714-2730.

Yousif, D.Y. 2018. Effects sprayed solution of salicylic acid to prevent of wilt disease caused by Fussarium oxysporium. J. Phys. Conf. Ser. 1003:012001.

Zhang, D.W., X.G. Deng, F.Q. Fu, and H.H. Lin. 2015. Induction of plant virus defense response by brassinosteroids and brassinosteroid signaling in Arabidopsis thaliana. Planta 241(4): 875-885.

Zhu, M., F.H. Li, and Z.S. Shi. 2016. Morphological and photosynthetic response of waxy corn inbred line to waterlogging. Photosynthetica 54(4):636-640. 